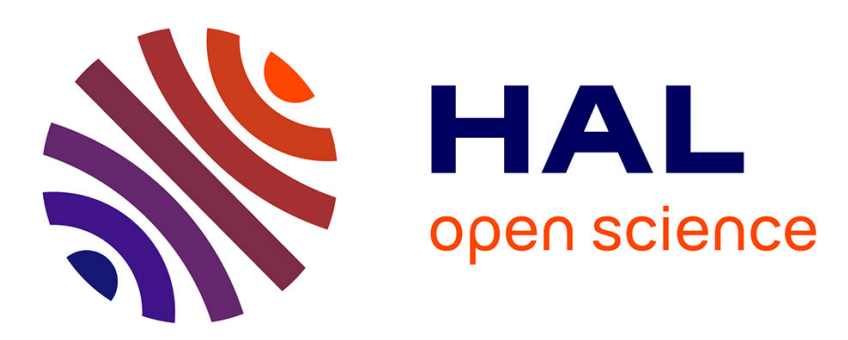

\title{
Woman in love, artist or entrepreneur? The edifying, mystifying life of Coco Chanel
}

Elen Riot

\section{To cite this version:}

Elen Riot. Woman in love, artist or entrepreneur? The edifying, mystifying life of Coco Chanel. Society and Business Review, 2013, 8 (3), pp.281-313. 10.1108/SBR-12-2012-0054 . hal-02883102

\section{HAL Id: hal-02883102 \\ https://hal.science/hal-02883102}

Submitted on 5 Jul 2020

HAL is a multi-disciplinary open access archive for the deposit and dissemination of scientific research documents, whether they are published or not. The documents may come from teaching and research institutions in France or abroad, or from public or private research centers.
L'archive ouverte pluridisciplinaire HAL, est destinée au dépôt et à la diffusion de documents scientifiques de niveau recherche, publiés ou non, émanant des établissements d'enseignement et de recherche français ou étrangers, des laboratoires publics ou privés. 
archives-ouvertes

\title{
Woman in love, artist or entrepreneur? The edifying, mystifying life of Coco Chanel
}

\author{
Elen Riot
}

\section{To cite this version:}

Elen Riot. Woman in love, artist or entrepreneur? The edifying, mystifying life of Coco Chanel. Society and Business Review, Emerald, 2013, 8 (3), pp.281-313. 10.1108/SBR-12-2012-0054 . hal02883102

\section{HAL Id: hal-02883102 \\ https://hal.archives-ouvertes.fr/hal-02883102}

Submitted on 5 Jul 2020

HAL is a multi-disciplinary open access archive for the deposit and dissemination of scientific research documents, whether they are published or not. The documents may come from teaching and research institutions in France or abroad, or from public or private research centers.
L'archive ouverte pluridisciplinaire HAL, est destinée au dépôt et à la diffusion de documents scientifiques de niveau recherche, publiés ou non, émanant des établissements d'enseignement et de recherche français ou étrangers, des laboratoires publics ou privés. 


\section{WOMAN IN LOVE, ARTIST OR ENTREPRENEUR? THE EDIFYING, MISTIFYING LIFE OF COCO CHANEL ELEN RIOT}

\section{Introduction}

Coco Chanel famously said: "Fashion passes, style remains." She demonstrated this view by creating a line of clothes that is easily identifiable, a classic of worldly elegance. Hundreds of pictures and thousands of columns have made her designs popular in the media. Powerful women tend to wear Chanel, associating their name with the brand and sporting its style, becoming one more on the long list of Chanel belles. In her time, Chanel seemed to be verywell aware of that fact, posing as a female erudito luxu, arbiter elegantiarum, a famous role in Western culture, personifying a system of representations well suited for the happy few. Avoiding the fate of Brummel, she skillfully used all available fabrics to build herself a durable robe for posterity. Chanel is credited with creating "a style" and this creation is the source of the successful strategy of her entrepreneurial venture.

Style is described by Roland Barthes (2006) as the heart of "the system of fashion," part of an ensemble combining real clothes, written clothes (in fashion magazines) and their inscription within a broader symbolic system made up of the connotations of dress codes in society. Semiotic analysis, embedding material objects into a social values system, also shows the role of fashion and style to frame social interactions. If building a fashion empire requires a high degree of entrepreneurship it is also highly specific in that most choices include an aesthetic dimension. What seems to be missing here, however, is the materiality of work practices that unifies the entrepreneurial venture and its artistic vision.

Recently, new approaches in entrepreneurship (Hjorth and Steyaert, 2009) have encouraged combining different views, among them semiotics and textual exegesis, to look at all kinds of ventures. Different kinds of stories (Hjorth, 2009; 2005; 2004) should make entrepreneurship a richer project than a mere business plan and yet, in many ways it is a territory that is quite alien to aesthetics because of this system of values. What people still associate with entrepreneurship is economic performance. So, what is interesting about entrepreneurship in relation to aesthetics is that it relates the materiality of the productive work system to various 
layers of representations associated with the figure of the entrepreneur or the nature of the transaction.

Going back to Barthes, we suggest that this new avenue for research looking at the aesthetics of entrepreneurship may be explored in the fashion industry to learn more about the nature of value creation and value in general. Fashion ventures are associated with creativity and entrepreneurship. In an age where creative industries are often presented as one of the most promising source of entrepreneurial ventures and innovation, there is an urgent need to describe and interpret this "creative" phenomenon and in particular, how art and economic values can coexist. To do so, one should pay attention to the creative, artistic nature of value creation in entrepreneurship, but should also wonder how it operates as a vision, that of a creator, involving other people at work. In our view, this phenomenon remains almost entirely unexplored to this day possibly because collective memory seems to disconnect art and style from productive work. We explore this question by using a specific example.

In this paper, we take the case of Coco Chanel as a real-life character who became an inspiration for a movie character. Three biopics were recently issued and received with considerable success. At the core of each movie is Coco's passion for fashion. This passion is related to the revelation of a unique gift for art and its public recognition. Despite many differences, all movies build a representation that corresponds to the ideal figure of the entrepreneur as a self-made (wo)man. However, I believe there is more to reality than what success stories reveal. In line with Barthes, semiotics may prove helpful here to deal with this symbol of fashion success.

In an attempt to "bring work back in" (Barley and Kunda, 2001) and to look beyond the storytelling and imagery of entrepreneurial myth-making, we explore Coco Chanel's work and life. According to André Malraux, the "Empress of Fashion" was said to be one of the three figures (together with De Gaulle and Picasso) that the world would remember about twentieth century France. She was one of the Times' 100 personalities of the twentieth century. Celebrating the woman behind the brand, in 2008 and 2009, three successful biographical movies portrayed Coco Chanel. We use these three movies, in contrast to biographies, and historical accounts to describe and interpret the dominant representations of a successful woman entrepreneur. Despite different stylistic choices, all stories seem to agree in 
portraying the heroic figure of a self-made woman who created a fashion empire at the cost of her personal life. We interpret these choices using semiotics and textual analysis in order to complement three more traditional approaches: entrepreneurship, feminist studies and narrative approaches. The goal is to analyze the influence of everyday life clichés on them.

More specifically, in contrast with the popular story that the movies and the brand website convey, we point out three missing dimensions behind the Coromandel screens of sentimentality, artistic friendship and feminine solidarity: business deals based on personal contacts, working conditions in haute couture and the fashion industry and the importance of public image and its codes in women's life as part of the "tournaments of value" (Appadurai, 1986) of modern times. This raises question about the role that aesthetics should play in telling us more about entrepreneurial ventures, work and society.

\section{Questioning the Traditional Figure of the Entrepreneur:}

Many aspects of the entrepreneurial phenomenon have been explored in relation to a theory of action. In contrast with more set traditions such as economics, psychology and sociology, aesthetics brings to life different aspects that may have been overlooked and in that regard, biopics prove interesting in their visual approach to entrepreneurship. However, in my view, the aesthetic view of entrepreneurship help us pay more attention to the way representations are constructed (1), to the implicit selection of skills that may help include certain profiles as capable of entrepreneurial ventures (for instance women) because of their knowledge and ability in aesthetics (2). Finally, aesthetics may be related to story-telling and the impression management accomplished by telling a pleasant tale (3). However, by uncovering the influence of aesthetics in shaping our view on entrepreneurship, we also discover at this point that using aesthetics to look at entrepreneurship includes a critical dimension. Namely, the anesthetization of entrepreneurial ventures may come with a heavy price.

\section{The Aesthetic Side of Entrepreneurship}

Pointing out the aesthetic side of entrepreneurship is a way of insisting on the creative nature of the embarking on new ventures. It means getting away from more traditional approaches, which would tend to focus on business models and entrepreneurial figures by uncovering implicit representations in relation to values. 
For instance, both Schumpeter (1991; 1944; 1934) and Druker (1985) point out the story and the actors behind the entrepreneurial project. The plot is one of "creative destruction" and the exploitation of a market opportunity. Although the stage has been set for a specific type of plot, it may need to evolve and include other types of actors and plots. Whether one talks about barefoot entrepreneurs (Imas et al., 2012) or about women, the story becomes enriched with more than just the challenge of obtaining funds and finding clients. The entrepreneurial project creates a tension between their different social roles (at work and at home, in their society and outside) and it may involve cultural changes (Guerrier, 2004; Gherardi, 1995) so as to articulate different value systems. Aesthetics allows us to look at the contradictions inherent to entrepreneurship without necessarily considering them a problem in the first place.

For instance, Foucault and de Certeau, Horth (2009) encourage us to take a more practiceoriented view of entrepreneurship. The inscription of the entrepreneurial venture in its specific time and space, its intentions in relation to its local inscription should be read as a genealogy of values. This would involve challenging the ready-made tales (often combined with such artifacts as PowerPoint slideshows and road-show business plans) by paying more attention to the actual performance of the entrepreneurial jest. This in turn may provide more information about the real profiles of entrepreneurs (Steyaert and Hjorth, 2009; Hjorth, 1999, 1998) and include a greater variety of profiles and skills. Two related ways of identifying specific differences, involving aesthetics, are feminist studies and narrative approaches.

\section{A Bigger Picture for the Entrepreneurial Profile}

One very good example of aesthetics in relation to the performativity of the role and the importance of the voice and the body is the case of women entrepreneurs of Moroccan origins in the Netherlands (Essers and Benschop, 2007). Reflecting about this experience as a researcher, one of the field-workers (Ellis, 2009) was able to capture traits of the woman entrepreneur that are often missed if one is only considering her as a silenced voice. In her efforts to impose herself in a world so far dominated by men, she is both in a position of inferiority compared to masculine professionals (Ortner, 1974) and, as an entrepreneur taking charge, in a position to play the part of the "phallic woman" (Butler, 2000; MacRobbie, 2009) in particular towards other men and women who are interacting with her as 
employees. In that regard, power issues between co-workers at work, between communities (at work, at home and in the public space) can be as complex as gender issues and one should not be dis-embedded from the others and prioritized. Using aesthetics could be a way to justify the specific power relations some women impose upon others, but it can also be a way to introduce more socio-material dimensions and to situate interactions in time and space. This makes a more varied range of stories.

\section{Stories about Entrepreneurs: Looking at the Making-Of}

Working on entrepreneurs, both Czarniawska (1998; 1997) and Gartner (2007) pointed at the importance of narration to better understand meaning through the way stories are composed. It seems that, although their approach to story-telling is different, both authors think that having different tales and different styles is important if we are to go beyond the stereotypes and myths introduced by representations. Taking into account the fact that this is why social analyses diverged from arts in the first place (Nelson et al., 2000), one may nevertheless use text analysis and exegesis to show that, in some of the representations commonly taken for granted in management and in particular, in entrepreneurship, one may still find a great deal of the stylizations and clichés that appeal to lovers of romance and kitsch.

This can be especially true in creative industries and fashion, where so much of the prestige and reputation of the products and services is related to their image. Skillful and stylish storytelling is compulsory to the point of being part of the brand.

Admitting that stories are (at least partly) fashioned for this effect, we may also better identify the role of aesthetics in relation to power issues. Since, as pointed-out by Lounsbury and Glynn (2003), stories are part of impression management and help define value during a road show, they are addressed towards an audience and they are meant to convey a specific message. However, the relationships between past events, the projected future and ongoing implementation of the plan are not simple to tell because of the multiplicity of people involved with different points of view. Generally, within a competitive field, an ordering of specific tales occurs and a common story ends up being transmitted, ideally shared by all. However, to better understand entrepreneurship and what it represents in society, one should be able 
to understand what the story is made of, in other words, to link representations to values (Graeber, 2001).

There are different aspects of the stories and, generally speaking, the story of the typical entrepreneur does correspond to a specific style of story telling (heroic tale) (Riot, 2006) and that it includes specific metaphors (Drakopoulou-Dodd and Anderson, 2001). We may also identify boundary objects and symbolic stages, which characters come through. Finally, the voice and the point of view from which the story is told also matter, because they correspond to specific stylistic genres and they influence understanding of what the characters do and what their environment does to them. They also shape the scenario and the pictures making up the mimesis. As we shall presently see, and as Barthes (1967) also pointed out, popular representations tend to favor novels and romances. Their type of structures influences the repertoire of characters and actions, and defines a universe of values. It is interesting to see how, in the case of the Coco Chanel biopics, this genre combines art and business by promoting the passion and ambition of a woman. Consequently, in using aesthetics, one may add a dimension that is key to identify the specificity of an entrepreneurial venture but also a dimension instrumentalized by key actors to hide the reality of practices and work conditions.

\section{Methodology:}

Our material is primarily composed of secondary data on Coco Chanel, and we focus on three movies of the "biopic" genre.

To look at the composition of movies as a specific format of representations, images in movement, we use semiotics. Common to several models of film analysis (Daney, 2012; Labarthe and Lounas, 2011). Studying signs involves combining text analysis (exegesis) and picture analysis in a multilevel message, the denoted (explicit) and the connoted (implicit). As such, it is at the meeting point of different traditions such as art history, comparative literature and philosophy. By insisting on the iconic nature of representations and their codes, one is also borrowing from a long religious tradition.

For instance, to capture representations and to dissect dominant representations made of symbols, rites and texts, many authors (Pink, 2006; Pink et al., 2004; Rose, 2007) insist on using a 
multidisciplinary approach to look at what can be seen and the narrative behind. One complex object of analysis is the creation of a "grammar of style" with its codes and variants.

As it happens, many of these authors have been influenced by the semiology tradition illustrated by Roland Barthes. His semiotic approach considers the specific characteristics of images and texts (Barthes, 1967) as systems of signs. Namely, he perceives a strong correspondence between the universe of discourse and the universe of visual images. To analyze them, he places them in a specific historically and materially situated background. Consequently, he looks both at the structure of an artwork and at its details, putting it in a context of production and a stylistic tradition.

In line with this approach, I first insist on the materiality of each movie and on its conditions of production. I then look at the genre of each narrative. In particular, we look at the type of storytelling used to account for the entrepreneurial venture of Coco Chanel. One initial problem was to deal with the "biopics" genre namely one confusing facts and fiction, taking liberty with reality to provide a meaningful portrait of a popular figure. This genre is often favored when dealing with famous entrepreneurs, since going into their everyday business would probably fail to convey the nature of their inspiration and the impact of their activities on society. Our view is that popular accounts such as biopics are received by the audience as something like "real life stories" as part of a large ensemble including stories with a higher or lower degree of "realia".

This view is supported by the nature of stories: even realist accounts correspond to a narrative construction so the distinction between fiction and reality is a challenging one to define. There is logic in telling a story that goes beyond accuracy and fiction. "To argue ... that the writing of ethnography involves telling stories, making pictures, concocting symbolisms, and deploying tropes is commonly resisted, often fiercely, because of a confusion, endemic in the West since Plato at least, of the imagined with the imaginary, the fictional with the false, making things out with making them up." (Geertz, 1988: 140). Although the fact may be hard to accept, the power of fiction cannot be denied. Consequently, the stuff that stories are made of is more accurately described in terms of combinations. It includes descriptions (mimesis), action (diegesis) framed by a particular point of view (voice). 


\begin{tabular}{|c|c|c|}
\hline Mimesis & Diegesis & Voice (perspective and intention) \\
\hline $\begin{array}{l}\text { Taussig (1993) referring to Auerbach } \\
\text { (2003) describes a combination of a } \\
\text { direct reflection of a socio-cultural } \\
\text { environment (picture, final } \\
\text { impression) and an orchestrated } \\
\text { device to create a "real effect" } \\
\text { (representation, tool) } \\
\text { Rose (2007) and Stanczak (2007) } \\
\text { insist on the stylization of pictures in } \\
\text { line with opposition of "real life } \\
\text { experience" and the artifice in the } \\
\text { representation of management } \\
\text { (Hancock, 2005, 2003). } \\
\text { Visual research should also be } \\
\text { critical and take into account the } \\
\text { impression management } \\
\text { orchestrated by the use of } \\
\text { pictures. }\end{array}$ & $\begin{array}{l}\text { Ellis and Bochner (1996) insist that } \\
\text { using visual data changes the nature } \\
\text { of the picture described within the } \\
\text { descriptive text and the } \\
\text { interpretation. } \\
\text { Gartner (1998) insists on the need } \\
\text { while researching entrepreneurship } \\
\text { to take stories into account in terms } \\
\text { of construction and narrative forms. } \\
\text { In cultural and artistic ventures, } \\
\text { pictures have a great importance } \\
\text { so as to share feelings and } \\
\text { emotions about the nature of the } \\
\text { production. }\end{array}$ & $\begin{array}{l}\text { Pictures extracted from real life or } \\
\text { from a movie such as a biopic are } \\
\text { considered as emblematic (Dougherty } \\
\text { and Kunda, 1990; Schwartz, 1989) } \\
\text { symbols of the whole. These } \\
\text { pictures are present in official } \\
\text { websites and press-books and } \\
\text { combined with discourse. } \\
\text { Silverman (2006) points out the ability } \\
\text { of visual methods to insert data for the } \\
\text { reader to see and identify different } \\
\text { layers of "real". When presenting } \\
\text { their results, researchers should be } \\
\text { aware of the potential of mixing } \\
\text { multimedia data to convey a richer } \\
\text { range of impressions to the reader. }\end{array}$ \\
\hline
\end{tabular}

What interests me in the nature of the "biopic" is the liberty taken with the original historical accounts to provide a good motion picture, corresponding to norms that have proven popular with the audience (for instance romance). These choices seem to be influenced by the aesthetics favored by large movie studios: polished neo-realism (Cavell, 1979) as a tool for entertainment but also dissemination of ideas. For instance, people learn their job through imitation (Czarniawska-Joerges and Rhodes, 2003: 203). This explains the influence of strong plots and the role of subversive counter-stories, rewriting dominant versions by selecting different representations. Consequently, to better understand about the version of an artistic entrepreneur suggested by the three biopics, I decided to document their initial material: the work and life of Coco Chanel.

I triangulated the data by combining the information contained in the three movies, their official press reviews and the textual references for the scenarios as well as other biographies documenting the life of Coco Chanel and women of her times (in particular workers and ordinary women). My key material is the three biopics on the character of Gabrielle Chanel: Coco Chanel (2008), Coco before Chanel (2009), Coco and Igor (2009), each of which is based 
on biographies of the main character (Charles-Roux, 1989; 1981; Delay, 1983; Madsen, 1990; Morand, 1976).

I also relate the movies to available documents on Chanel today, press reviews, communication tools such as Karl Lagerfeld's short movies (available on the website) and Loïc Prigent's 2006 documentary on the preparation of the final Chanel show in the seamstress's rue Cambon workshop.

Finally, I gathered historical data about couture in France after the industrial revolution from 1900 to 1939. I was especially interested in the relationship between Coco Chanel and large industrialists, for instance the Balsan family (Mery-Barnabé, 2010) and the Wertheimers. The rich documentation on the history of fashion (Boucher, 1965; Grau, 2007; Müller, 2008; Steele, 2005; 1999) allowed me to identify the nature of innovation and the type of entrepreneurs in relation to the Parisian work force and work conditions in the industry. By combining these three dimensions (story, image and voice) I hope to provide a contrasting synthesis of how representations popularize famous entrepreneurs for very large audiences. In this particular case, artistic talent and inspiration is associated with the loss of a personal sentimental balance for the key character: Coco Chanel, the entrepreneur.

\section{Three Popular Biopics about Coco:}

In my analysis of the material I gathered, I focus on three movies that were enormously successful. After describing their features as cultural objects (1), I analyze the plot (diegesis) (2) and finally focus on the key symbols and images (mimesis) they contain (3). My goal is to capture the common patterns and differences between the different movies so as to better picture the character of Coco Chanel, the embodiment of the successful fashion entrepreneur in popular culture.

1. Three movies: One Plot

The three movies I shall be looking at are somehow similar in many points: they benefitted from a large production budget and a very large audience, millions of people around the world saw them. They were released at about the same time (2008-2009) and they received critical 
acclaim. They are also all successful, mainstream productions with popular actors and models and typical features (drama-romance) with a plot lasting about 2 hours.

\begin{tabular}{|c|c|c|c|}
\hline & Coco before Chanel & Coco \& Igor & Coco Chanel \\
\hline Director & Anne Fontaine & Jan Kounen & Christian Duguay \\
\hline Adaptation from & $\begin{array}{l}\text { Edmonde Charles-Roux, } \\
\text { L'irrégulière } \\
\text { (script by A. Fontaine } \\
\text { freely inspired from) }\end{array}$ & $\begin{array}{l}\text { Chris Greenhalgh, } \\
\text { Coco \& Igor } \\
\text { (also author of the } \\
\text { screenplay) }\end{array}$ & $\begin{array}{l}\text { Edmonde Charles-Roux, } \\
\text { L'Irrégulière }\end{array}$ \\
\hline Key actors & $\begin{array}{l}\text { Audrey Tautou (also } \\
\text { model for Chanel) }\end{array}$ & $\begin{array}{l}\text { Anna Mouglalis (also } \\
\text { model for Chanel) }\end{array}$ & $\begin{array}{l}\text { Barbara Bobulova and } \\
\text { Shirley McLaine }\end{array}$ \\
\hline genre & Drama & Drama romance & $\begin{array}{l}\text { Drama } \\
2 \text { episodes (3h in total) }\end{array}$ \\
\hline awards & $\begin{array}{l}\text { Cannes Festival } \\
\text { nomination }\end{array}$ & $\begin{array}{l}\text { Cannes Festival } \\
\text { nomination }\end{array}$ & $\begin{array}{l}\text { Golden Globe } \\
\text { Nominations }\end{array}$ \\
\hline production & $\begin{array}{l}\text { France 2, Cine Cinema, } \\
\text { Canal + (Fr) }\end{array}$ & $\begin{array}{l}\text { Eurostal Production } \\
\text { Canal }+(\text { Fr) }\end{array}$ & $\begin{array}{l}\text { Lifetime (US), Rai TV } \\
\text { (It), France } 2\end{array}$ \\
\hline budget & $\$ 23$ million & N.A. & $\$ 23$ million \\
\hline $\begin{array}{l}\text { Box office Income } \\
\text { (home/abroad) }\end{array}$ & $\begin{array}{l}\$ 1.6 \text { million } / \$ 4.134 \\
\text { million ( } 72 \% \text { outside } \\
\text { France) }\end{array}$ & $\begin{array}{l}\$ 6 \text { million } / \$ 44 \text { million } \\
\text { (88\% outside France) } \\
100000 \text { in France }\end{array}$ & N.A. (released on TV) \\
\hline Date released & 2009 & 2009 & 2008 \\
\hline
\end{tabular}

The three productions celebrate the $100^{\text {th }}$ anniversary of the opening of the first Chanel boutique in Paris in 1910. The movies are historical reconstitutions and are "biopics", mixing biography and epic forms.

Given the impact of their distribution, all three movies were highly successful around the world, which shows the appeal of fashion in different cultural traditions in line with the popularity of fashion magazines. It is also a reflection on the celebrity of this successful entrepreneur and the considerable budgets parallel those of traditional communication campaigns by Chanel, although here each project is independent from the "maison Chanel" (it just depends on copyrights).

However, the three movies all being biopics should not hide the fact that they adopt a different approach and are variations on the life of Coco Chanel. They all claim to tell the "true story" of Coco Chanel, and thereby to explain the success of the entrepreneur through her life story. However, they explain this success differently. To make these differences appear, I now provide a short, matter of fact "entrepreneurial style" account of Coco Chanel's venture as a reference for the three "biopic" variations. 


\begin{tabular}{|l|l|}
\hline Periods & Events \\
\hline $\begin{array}{l}\text { Youth and } \\
\text { learning }\end{array}$ & $\begin{array}{l}\text { Chanel's parents are related to selling clothes and sewing. They are poor in rural France and } \\
\text { she ends up an orphan in a convent. She then makes a living as a seamstress and as a cabaret } \\
\text { singer. }\end{array}$ \\
\hline Start-up & $\begin{array}{l}\text { Chanel is supported by rich sponsors (love money) to open her shop of prêt-à-porter in Paris. } \\
\text { She opens in seaside resorts. Her venture is successful because of World War 1 and its } \\
\text { disruption. }\end{array}$ \\
\hline growth & $\begin{array}{l}\text { Diversification in haute couture, perfume, cosmetics and accessories (jewels) via a series of } \\
\text { alliances }\end{array}$ \\
\hline decline & $\begin{array}{l}\text { The Front Populaire and World war 2 causes Chanel to close her shop (the perfume is still } \\
\text { sold). }\end{array}$ \\
\hline rebirth & $\begin{array}{l}\text { After the war, Chanel raises again at the head of the firm supported by her US partners } \\
\text { (cosmetics industrialists) who have the perfume sales in mind. }\end{array}$ \\
\hline Re-rebirth & $\begin{array}{l}\text { After Chanel's death, Karl Lagerfeld revitalizes the brand in the 1980s after a long period of } \\
\text { decline. He uses Coco and her life as an inspiration. }\end{array}$ \\
\hline
\end{tabular}

All movies present a limited period of the life of Coco Chanel, mostly focusing on her love life and the beginning of her business. To entrepreneurial entrepreneurial venture, it is important to understand the early age and the foundations, so it is quite an interesting document. However, for this purpose, the obstacle would be that the business venture is essentially the context and the setting of Chanel's love life in all three movies. The message, to me, is that Chanel's emotional life shaped her style and that of her house much more than the everyday work of all her team.

\section{Variations in Genre and Narrative Styles:}

So far, the storyline of the three biopics was surprisingly similar (in line with the corporate communication of the brand present on the website and also in various publications and shows). However, in terms of genre and style, biopics present several differences.

The three biopics correspond to different versions of the same reproduced reality. Comparing the three variations makes it easier to see how they all recreate an "allegory" of Gabrielle Chanel, in relation to an existing, highly successful enterprise: a luxury brand associated with elegance and style. However, each movie selected a different aesthetic to do so.

\begin{tabular}{|c|c|c|c|}
\hline & Coco before Chanel & Coco \& Igor & Coco Chanel \\
\hline Genre & $\begin{array}{l}\text { Bildungsroman (tale of } \\
\text { experience) }\end{array}$ & romance & serial \\
\hline Style & Classicism & Expressionism & Romance (Soap) \\
\hline $\begin{array}{l}\text { Elements of style and } \\
\text { patterns }\end{array}$ & $\begin{array}{l}\text { Harmony: } \\
\text { Black and white } \\
\text { Simplicity (rich and } \\
\text { poor) } \\
\text { Androgyny (man and }\end{array}$ & $\begin{array}{l}\text { Contrast: } \\
\text { Black and white vs. } \\
\text { colours } \\
\text { Old timers vs. } \\
\text { innovators }\end{array}$ & $\begin{array}{l}\text { Opposition: } \\
\text { Rich and poor } \\
\text { Men and women } \\
\text { Good and evil } \\
\text { (adjuvants/opponents) }\end{array}$ \\
\hline
\end{tabular}




\begin{tabular}{|l|l|l|l|}
\hline & $\begin{array}{l}\text { woman) } \\
\text { Style (nature and } \\
\text { artifice, horses vs. cars) }\end{array}$ & $\begin{array}{l}\text { Dissonance and excess } \\
\text { in relation to passion vs. } \\
\text { sickness-melancholy- } \\
\text { weakness and service }\end{array}$ & Workers and idle \\
\hline moral & $\begin{array}{l}\text { Coco finds her vocation } \\
\text { through a man who } \\
\text { loves her and sees in } \\
\text { her talent and a unique } \\
\text { destiny. }\end{array}$ & $\begin{array}{l}\text { Both Coco and Igor } \\
\text { triumph in creating an } \\
\text { unforgettable artwork } \\
\text { (the Rite of Spring) and } \\
\text { imposing it on the } \\
\text { public. Art survives the } \\
\text { end of their love and } \\
\text { makes it last forever. }\end{array}$ & $\begin{array}{l}\text { Coco comes back to } \\
\text { work in 1953-1954 and } \\
\text { she endures hardship as } \\
\text { she always did } \\
\text { throughout her life } \\
\text { (orphan, exploited, and } \\
\text { losing the love of her } \\
\text { life). Her second } \\
\text { collection is a triumph. } \\
\text { Her life is a source of } \\
\text { inspiration and explains } \\
\text { why she is a leader. }\end{array}$ \\
\hline
\end{tabular}

All movies chose Coco's love life as the pivot for her enterprise, they also insist on her predominant role in producing the "Chanel style," namely the fashion associated with Chanel is embedded in her life. The emotional and aesthetic dimensions of the venture materialize the vision, and the nature of this vision depends on the figure of "the woman."

Despite this convergence, one may still note differences in genre: one is a tale of experience (a girl from 5 to 30), the other is a romance between two famous figures whereas the last production is a TV serial orchestrated around the revenge of old Coco in 1953. The corresponding styles are also divergent. One movie is deliberately "expressionist" and describes Coco as the queen of Parisian fashion, patron of artists, whereas the two other ones insist on the "moral value" of her success, as an entrepreneurial success based on creative destruction (the end of the old fashion world, embodied by a series of characters in the Coco's background). Yet whereas Coco Chanel is intent on picturing the heroin as a nice girl with a difficult life, Coco before Chanel presents a more contrasted picture of the character. She is tough; she swears, lies and displays signs of rebellion against the social system. This difference is, however, smoothed out by the very polished visual treatment of the topic quite similar to that of the two other biopics: naturalism-realism of the historical reconstitution. To achieve this aesthetic balance, all three movies also use the same diegetic type: an omniscient voice and a chronological narrative. 
As illustrated in the following chart, voice and focus (lens, zoom) (Nicolini, 2009) impose a traditional view on characters, essentialized as transparent, stable beings submitted to a series of trials as in a fairy-tale:

\begin{tabular}{|c|c|c|c|}
\hline & Coco before Chanel & Coco \& Igor & Coco Chanel \\
\hline voice & $\begin{array}{l}\text { External focus, omniscient view of } \\
\text { characters }\end{array}$ & $\begin{array}{l}\text { External focus, omniscient view of } \\
\text { characters }\end{array}$ & $\begin{array}{l}\text { Double focus combining a } \\
\text { neutral, objective voice } \\
\text { and the voice of Coco } \\
\text { Chanel recalling her } \\
\text { vouth }\end{array}$ \\
\hline time & $\begin{array}{l}\text { Coco, from } 8 \text { to } 30 \\
\text { Key episodes with a string of } \\
\text { scenes, omissions (years and } \\
\text { months) }\end{array}$ & $\begin{array}{l}\text { Coco, from } 30 \text { to } 75 \\
\text { Key episodes with omissions ( } 10 \\
\text { years, a few month, } 50 \text { years) }\end{array}$ & $\begin{array}{l}\text { Coco, from } 8 \text { to } 70 \\
\text { Key episodes with } \\
\text { omissions justified by } \\
\text { flash-backs }\end{array}$ \\
\hline setting & $\begin{array}{l}\text { Rural France and the countryside, } \\
\text { Deauville and Paris } \\
\text { Most scenes happen indoors } \\
\text { (intimacy) yet contrast with } \\
\text { crowds (horse races, theater, } \\
\text { fashion shows) }\end{array}$ & $\begin{array}{l}\text { Contrast between the house } \\
\text { (intimacy) and the stage (the Rite of } \\
\text { Spring and the fashion show) }\end{array}$ & $\begin{array}{l}\text { Contrast between the } \\
\text { fashion house rue } \\
\text { Cambon and France's } \\
\text { past (rural and Parisian) }\end{array}$ \\
\hline
\end{tabular}

In all cases, the diegesis orchestrates this series of trials as a sentimental game ruled by fate (love at first sight and death). However, this strict narrative frame is balanced by mimesis and the descriptive pauses where the visual impact of images (stadium and punctum) and is exploited. Scenes and images provide a fine-grained view of each movie, as such, they point at the composition of the representations underlying the structure of the diegesis.

3. Sentimentalism and Aesthetization: The double frame of tale and images

As is traditionally the case in movies, the central action is created by a string of exemplary situations and turning points presented in scenes (Cavell, 1981; Daney, 2012). As illustrated in the following summary of the three movies, the scene selection is quite similar in that it favors intimacy and assimilates the resolution of the heroin's love life with her professional career.

\begin{tabular}{|l|l|l|l|}
\hline & Coco before Chanel & Coco \& Igor & Coco Chanel \\
\hline Childhood trauma & $\begin{array}{l}\text { Coco is left with her } \\
\text { sister in the Aubazine } \\
\text { convent as an orphan. } \\
\text { Childhood trauma. }\end{array}$ & $\begin{array}{l}\text { Absent except in } \\
\text { Coco's interest } \\
\text { for Igor's } \\
\text { children, } \\
\text { especially a little } \\
\text { girl she dresses } \\
\text { in black. }\end{array}$ & $\begin{array}{l}\text { Coco's mother dies in front of } \\
\text { her; she ends up in the } \\
\text { convent and finds a job as a } \\
\text { seamstress. } \\
\text { The poor girl wants to escape } \\
\text { her condition. }\end{array}$ \\
\hline $\begin{array}{l}\text { Song and origin of the } \\
\text { name "Coco" }\end{array}$ & $\begin{array}{l}\text { With her cousin, Coco } \\
\text { sings in a low-key }\end{array}$ & $\begin{array}{l}\text { Coco is already a } \\
\text { reference in }\end{array}$ & $\begin{array}{l}\text { Coco is noticed by Balsan as } \\
\text { she is singing "Coco" and he }\end{array}$ \\
\hline
\end{tabular}




\begin{tabular}{|c|c|c|c|}
\hline & $\begin{array}{l}\text { cabaret (French: } \\
\text { "beuglant") where she } \\
\text { meets Etienne Balsan. } \\
\text { She is singing a simple } \\
\text { song with an erotic } \\
\text { double-entendre "Coco." } \\
\text { Coco is strong and } \\
\text { original because she has } \\
\text { had difficult experiences } \\
\text { in her youth. }\end{array}$ & Paris. & $\begin{array}{l}\text { treats her as his possession. As } \\
\text { a result, she decides to create } \\
\text { her own business. She ends up } \\
\text { in misery because her Paris } \\
\text { business is failing. } \\
\text { Coco is a fragile creature } \\
\text { despite all her courage. }\end{array}$ \\
\hline Social humiliation & $\begin{array}{l}\text { Coco is kept by Balsan } \\
\text { and depends on him. } \\
\text { She is forced to sing } \\
\text { "Coco" again. She } \\
\text { refuses to marry him } \\
\text { when she falls in love } \\
\text { with Capel. She } \\
\text { maintains she will never } \\
\text { be married. } \\
\text { Coco is a pioneer in } \\
\text { wanting economic } \\
\text { independence first. }\end{array}$ & $\begin{array}{l}\text { Coco has risen to } \\
\text { be a star but she } \\
\text { still works } \\
\text { constantly and } \\
\text { counts } \\
\text { banknotes. Igor } \\
\text { tells her she is } \\
\text { just a popular } \\
\text { milliner, not an } \\
\text { artist at what she } \\
\text { retorts she is } \\
\text { more famous } \\
\text { than he is. }\end{array}$ & $\begin{array}{l}\text { Coco is humiliated as a } \\
\text { seamstress and then as } \\
\text { Balsan's mistress. She finds } \\
\text { comfort in horses (nature) and } \\
\text { hats (culture and creation). } \\
\text { Boy's support is crucial to } \\
\text { Coco's success (assumption } \\
\text { that the problem is the rigidity } \\
\text { and decadence of French } \\
\text { society because of the idle } \\
\text { classes. } \\
\text { Coco is a feminist. }\end{array}$ \\
\hline $\begin{array}{l}\text { Inspiration: Chanel } \\
\text { stealing from the world } \\
\text { around her }\end{array}$ & $\begin{array}{l}\text { Coco meets high society } \\
\text { people and offers to } \\
\text { share her fashion } \\
\text { creations (androgynous, } \\
\text { unadorned and } \\
\text { provocative). } \\
\text { Her boutiques in Paris } \\
\text { and Deauville are very } \\
\text { popular. } \\
\text { The Coco style means } \\
\text { good taste (beyond class } \\
\text { culture). }\end{array}$ & $\begin{array}{l}\text { Coco finds an } \\
\text { embroidered } \\
\text { Russian shirt } \\
\text { (roubachka) in } \\
\text { her rival's } \\
\text { cupboard. She } \\
\text { decides to use the } \\
\text { idea and make it } \\
\text { hers, namely } \\
\text { sophisticated. } \\
\text { The Coco style } \\
\text { transforms trivial } \\
\text { objects into } \\
\text { sophisticated, } \\
\text { rare objects for } \\
\text { the happy few. }\end{array}$ & $\begin{array}{l}\text { Coco observes various places } \\
\text { where fashion is on display: } \\
\text { horse-races, balls, seaside } \\
\text { resorts. During the war, Coco } \\
\text { creates convenient dresses for } \\
\text { women and becomes } \\
\text { prestigious. } \\
\text { The Coco style means both } \\
\text { practical and romantic. }\end{array}$ \\
\hline $\begin{array}{l}\text { Death of Boy Capel and } \\
\text { reaction of Chanel }\end{array}$ & $\begin{array}{l}\text { Coco learns about the } \\
\text { death of Capel, and } \\
\text { choses to go and see the } \\
\text { site of the accident. She } \\
\text { then creates the little } \\
\text { black dress and other } \\
\text { dresses. } \\
\text { Creation replaces love } \\
\text { (sublimation). }\end{array}$ & $\begin{array}{l}\text { The movie starts } \\
\text { with a scene of } \\
\text { Coco and Boy. } \\
\text { The movie } \\
\text { pictures them as } \\
\text { a modern } \\
\text { (outside } \\
\text { bourgeois } \\
\text { conventions), } \\
\text { very fashionable) } \\
\text { couple. } \\
\text { Love and creation } \\
\text { are the same } \\
\text { thing (sturm und } \\
\text { drang, storm and } \\
\text { stress). }\end{array}$ & $\begin{array}{l}\text { Coco learns about the death of } \\
\text { Capel, and chooses to go and } \\
\text { see the site of the accident. She } \\
\text { then creates the little black } \\
\text { dress and other dresses. } \\
\text { Working for others is Coco's } \\
\text { vocation (in line with her } \\
\text { education by the good nuns). }\end{array}$ \\
\hline Meeting with artists & $\begin{array}{l}\text { Coco has attempted to } \\
\text { be a singer and fits } \\
\text { costumes for } \\
\text { actresses/courtesans }\end{array}$ & $\begin{array}{l}\text { In the second } \\
\text { sequence, Coco } \\
\text { attends the } \\
\text { scandalous }\end{array}$ & $\begin{array}{l}\text { Coco increasingly surpasses } \\
\text { Paul Poiret (presented as old } \\
\text { style and bad taste) by using } \\
\text { actresses and the media. She }\end{array}$ \\
\hline
\end{tabular}




\begin{tabular}{|c|c|c|c|}
\hline & $\begin{array}{l}\text { (backstage). She is still } \\
\text { involved in light low- } \\
\text { key shows. Cultural } \\
\text { studies would approve } \\
\text { the mix of cultures. }\end{array}$ & $\begin{array}{l}\text { opening night of } \\
\text { Diaghilev and } \\
\text { Stravinsky's Rite } \\
\text { of Spring. She is } \\
\text { amused. } \\
\text { Coco is part of an } \\
\text { elite avant-garde } \\
\text { movement (future } \\
\text { recognition for } \\
\text { cubism and } \\
\text { modernism). }\end{array}$ & $\begin{array}{l}\text { becomes a fashion icon. Coco is } \\
\text { in line with the demands of her } \\
\text { time }\end{array}$ \\
\hline $\begin{array}{l}\text { Moment in boutique } \\
\text { (Chanel at work) }\end{array}$ & $\begin{array}{l}\text { On several occasions, } \\
\text { Coco is presented } \\
\text { drawing dresses and } \\
\text { costumes. She is rather } \\
\text { a lonely figure and no } \\
\text { conflict with her } \\
\text { workers is presented. In } \\
\text { the story, Coco designs } \\
\text { dresses for herself and } \\
\text { her friends, inspired by } \\
\text { simple people's dresses } \\
\text { and then copies are } \\
\text { made. Coco is essentially } \\
\text { authentic. She succeeds } \\
\text { on her own. }\end{array}$ & $\begin{array}{l}\text { Chanel goes back } \\
\text { and forth from } \\
\text { her villa near } \\
\text { Paris (where } \\
\text { Stravinsky and } \\
\text { his family are } \\
\text { living) and her } \\
\text { shop. She } \\
\text { inspects } \\
\text { everything; } \\
\text { obviously she } \\
\text { works all the } \\
\text { time as she chain- } \\
\text { smokes. But she } \\
\text { is roguish with } \\
\text { everyone (all } \\
\text { classes included). } \\
\text { Coco is essentially } \\
\text { a genius and a } \\
\text { highly } \\
\text { sophisticated } \\
\text { creator. She } \\
\text { succeeds on her } \\
\text { own. }\end{array}$ & $\begin{array}{l}\text { Coco is presented as a good } \\
\text { person, supported by other } \\
\text { women in contrast with the } \\
\text { meanness of her boss (a } \\
\text { woman in a provincial town) } \\
\text { when she was a seamstress. } \\
\text { Coco is essentially a nice person } \\
\text { with a great destiny. She } \\
\text { receives the support of clever } \\
\text { businessmen to succeed. }\end{array}$ \\
\hline $\begin{array}{l}\text { Creation of Chanel No. } 5 \\
\text { in Grasse }\end{array}$ & $\begin{array}{l}\text { The scene is not } \\
\text { present. } \\
\text { Objects appear as } \\
\text { convenient inventions to } \\
\text { fit the needs of a } \\
\text { modern, free woman. }\end{array}$ & $\begin{array}{l}\text { Coco invents the } \\
\text { perfume, with } \\
\text { Ernest Beaux as a } \\
\text { contributor. She } \\
\text { gives it her name } \\
\text { as a sign of her } \\
\text { appetite for fame } \\
\text { and for power. } \\
\text { Object as a must. }\end{array}$ & $\begin{array}{l}\text { Coco invents the perfume, } \\
\text { with Ernest Beaux as a } \\
\text { contributor. She is still } \\
\text { desperate about Boy's death. } \\
\text { Object as comfort. }\end{array}$ \\
\hline $\begin{array}{l}\text { Chanel in the staircase, } \\
\text { contemplating her } \\
\text { collection as it is shown } \\
\text { to the public }\end{array}$ & $\begin{array}{l}\text { Coco is happy at last as } \\
\text { she smokes her } \\
\text { cigarette at the top of } \\
\text { her staircase. From now } \\
\text { on, she remains } \\
\text { backstage. } \\
\text { Fate: ascension }\end{array}$ & $\begin{array}{l}\text { The event of the } \\
\text { fashion show is } \\
\text { paralleled with } \\
\text { the second } \\
\text { opening night of } \\
\text { the Rite of Spring. } \\
\text { She is therefore } \\
\text { an artist, a } \\
\text { partner of artists } \\
\text { and a sponsor of } \\
\text { other artists. She } \\
\text { uses other artists } \\
\text { as an inspiration } \\
\text { for her arts. She } \\
\text { replaced Misia }\end{array}$ & $\begin{array}{l}\text { In a series of flashbacks } \\
\text { (beginning of each sequence) } \\
\text { in } 1953 \text { and then in } 1954 \text { Coco } \\
\text { refers to the past as a source } \\
\text { of legitimacy for her } \\
\text { comeback. She convinces her } \\
\text { business partner and friend, } \\
\text { Paul Wertheimer. } \\
\text { Fate: happy-end after ups and } \\
\text { downs }\end{array}$ \\
\hline
\end{tabular}




\begin{tabular}{|l|l|l|l|}
\hline & & $\begin{array}{l}\text { Sert in the } \\
\text { patron's loggia. } \\
\text { Fate: ascension. }\end{array}$ & \\
\hline
\end{tabular}

The comparison of the three movies in the chart above points out that all the movies cut through Coco Chanel's life via these scenes, and, because they are mostly interested in the young woman, they ignore the same events. There are lots of tears (traces of the emotional life of the main character (Cavell, 1996)) in the three biopics, because they are structured as a series of personal losses for Coco: loss of her parents, loss of her lovers. All the scenarios seem to conclude that, although the heroin's private life is somehow a failure (she ends up alone), this was the price to pay for her exceptional professional success. Even when she is old, Coco, played by Shirley McLaine, seems to find her inspiration in her youth, when the center of her life was love. Yet when documenting this matter, it appears that Coco Chanel's life lasted more than 70 years, and that the two world wars were major events. Two movies select moments before the wars, or between them. The third movie follows two collections (1953 and 1954) and includes flashbacks in a chronological order. Some of the six flashbacks are introduced by old black-and-white films showing the streets of Paris. However, the choice to stage her early life, then youth, then life at Etienne Balsan's, then life with Boy Capel (including the war period), then the end of her life together with Capel's death involves numerous distortions. The main silence concerns Coco Chanel's life between her 40s and 50s, especially the Second World War during which she played a very controversial role. Recently (Vaughan, 2011), she has been portrayed as a Nazi spy, and a drug addict, aspects which, contrary to her (reported) homosexuality, are not acceptable today. Some of the most controversial dimensions of Chanel's are, however, not totally absent from the movies but they are conveyed by indirect means, mimesis.

\section{The Complementary Frame to Diegesis: Mimesis in Telling Images}

Despite the telling silence of all three plots, many aspects of Coco Chanel's life, some of which make it quite exceptional, seem to have been alluded to using images instead of being simply ignored. This seems to be related to Chanel's core business: aesthetics and more specifically, fashion. As any true artist, Coco Chanel's gift is potentially dangerous for herself and for others, and this romantic dimension is not absent from the biopics. Once again, the grid provided for this message is surprisingly similar in the three movies, to the point that it seems to complement the frame offered by the diegesis in a very uniform coding. 
In a sense, the story of Chanel's life must be contextualized, and the key periods of her life are the same, so similar events happen. Yet the mix of informative details is also complemented by a series of "images" which also appear in Chanel's official communication, for instance the recent clips by Karl Lagerfeld. There is nothing surprising in this: pictures (mimesis) complement the narrative (diegesis) either by illustrating the facts (studium) or by introducing emotional pauses (punctum) (Barthes, 1981). But in the specific case at stake, their combination constitutes a complementary, synchronic grid, to the diachronic steps of the chronology and both are quite similar in all three movies.

To investigate this surprisingly similar framing and consistent with Barthes' (1981) dichotomy (stadium/punctum), I present a selection of the "official pictures". I attempted to identify Chanel's symbols common to all movies, and their specific treatment in each movie.

The first pictures that one views before seeing the movies are the movie posters. They were accessed via the website IMDb (Internet movie database) an online resources concentrating all movie pictures on the world. On the main page of each movie, it presents one or two posters and a synopsis.

\section{INSERT FIGURE 1 ABOUT HERE}

All three posters focus on Coco, as the heroin of the movie and they show her face in close-up, yet apart from that, the face is treated quite differently. The first picture is a close-up view of actress Audrey Tautou who was also the current face of Chanel. The character is deliberately androgynous and natural (green grass in the background) and she seems to be walking forward, looking to one side in a determined way. This picture corresponds to the psychological treatment of the evolution of the main character, in the tradition of the bildungsroman.

\section{INSERT FIGURE 2 ABOUT HERE}

It should be noted that another poster was selected for the French audience, because the law is more tolerant of cigarettes and sexually explicit images for a broad audience, as the director 
explains in her commentary of the movie. Dressed in white pajamas Coco sits in a white bed, smoking and staring in front of her. In this image, the dominant black-and-white theme that is portrayed in the movie is much more present and the poster is closer to Tautou's Chanel ads. The resemblance between the two women (with pearls) contrasts with the boyish nature of the ads, focusing on youth and androgyny (pajamas, shirt and waistcoat). Consequently, one is left to wonder if professional success is associated with sexual equality or if it implies that, if they want to succeed, women have to adopt masculine standards.

The "Coco and Igor" poster illustrates the romantic involvement of the two characters, thereby justifying the genre "romance" in the movie database category (as opposed to the "drama" categories selected for the two other movies). The two characters are fondly cuddling but one can see only their profiles in bust and in a blurry light. The picture is representative of the close-up choice of the movie, focusing on the psychology of both lovers, and balancing their parallel evolution.

The Coco Chanel poster consists on an art-deco black and gold background, with a picture of Shirley McLaine (Chanel at 70) in the center. Dressed in black and white with a beret, she stands out as the "Empress of fashion". The picture is reminiscent of that of a musical, and it may very well be a reminder of the famous musical, Coco, initially staged in Broadway in 1969. This approach is illustrating the resilience of the woman, insisting on the length of her career and her passion for her craft.

All three movies are presented to their audience as a show that bringing together film stars, glamorous costumes and settings, and, most of all, a love story. However, the first poster (in its French version) hints at the non-conformist nature of Coco Chanel's life, as told by her biographers. In an allusion to her liberated sexuality, the source of many professional encounters, Coco is presented in a bed and in man's pajamas. Her smoking a cigarette may also be a reference to her drug addiction.

Going back to the movies, some of the specific symbols present in the posters are also recurrent along the scenes. They convey the main messages of the story repeatedly acting as "punctum" of the movie picture identified by Barthes as the specific characteristic of cinematic 
work. Barthes specifically refers it to the "obtuse" response in the spectator, a kind of emotional sensemaking prompted by impressions ${ }^{1}$.

One recurrent image is that of the couple, showing the importance of love in Coco Chanel's life. However, this image is so common to movies of that sort that it fails to characterize the movie by combining "studium" and "punctum". The only signifying different is, in my view, the Japanese poster for the movie Coco and Igor, which pictures the two characters in two universes: Coco, sitting in her loggia as a patron of the arts, and Stravinsky working on his piano. This choice describes two objective roles (studium) but it also provides a true picture of their relation in the movie: Coco needs the work of Igor to win her social battle.

\section{INSERT FIGURE 3 ABOUT HERE}

On the contrary, the following chart lists recurring elements about the Chanel story to the point when, in my view, they create a complementary, synchronic frame, for the picture.

\begin{tabular}{|c|c|c|c|}
\hline & studium & punctum & meaning \\
\hline $\begin{array}{l}\text { Black and } \\
\text { white, } \\
\text { pajamas and } \\
\text { androgynous } \\
\text { dress }\end{array}$ & $\begin{array}{l}\text { Chanel is changing fashion } \\
\text { by taking influences in, so } \\
\text { far, different universes } \\
\text { (men, professional dress); } \\
\text { she takes her inspiration in } \\
\text { her lovers. }\end{array}$ & $\begin{array}{l}\text { Chanel did that because she was } \\
\text { different, her originality is presented in } \\
\text { relation to her origins and position in } \\
\text { the world. } \\
\text { Chanel also had a different relation with } \\
\text { men, she was their equal. }\end{array}$ & $\begin{array}{l}\text { Radicalism, avant- } \\
\text { garde, purism }\end{array}$ \\
\hline Pearls & $\begin{array}{l}\text { Chanel launched the fashion } \\
\text { of "fake jewels" in high } \\
\text { society with very large } \\
\text { (impossibly big) stones. } \\
\text { Playing with representations } \\
\text { is a way of liberating } \\
\text { women. }\end{array}$ & $\begin{array}{l}\text { Chanel is creating her own kingdom and } \\
\text { at the same time, creating more than a } \\
\text { tie, a leash with her prestigious work. } \\
\text { She is chained with creation as the } \\
\text { sisters with their rosary (in the } \\
\text { beginning of the movie) have given their } \\
\text { life to the house of God. }\end{array}$ & $\begin{array}{l}\text { Chains (often } \\
\text { associated with } \\
\text { scissors) are binding } \\
\text { consequently, they } \\
\text { are both a valuable } \\
\text { asset and a freedom } \\
\text { issue. }\end{array}$ \\
\hline $\begin{array}{l}\text { Cigarette } \\
\text { (see Figure } \\
\text { 4) }\end{array}$ & $\begin{array}{l}\text { Flappers started smoking } \\
\text { like men at that time and } \\
\text { this was } \quad \text { highly } \\
\text { controversial. }\end{array}$ & $\begin{array}{l}\text { Chanel is surrounded by the smoke of } \\
\text { scandal (because her liberated love-life } \\
\text { and her drug addiction). This possibly } \\
\text { influences her when creating artificial } \\
\text { paradises. }\end{array}$ & $\begin{array}{l}\text { Transgression, } \\
\text { relation to death } \\
\text { (visible in } \\
\text { cigarettes) is such as } \\
\text { strong symbol that is } \\
\text { explains why some } \\
\text { of the posters were } \\
\text { banned in some } \\
\text { countries. }\end{array}$ \\
\hline
\end{tabular}

\footnotetext{
1 «Je crois que le sens obstus porte une certaine émotion; prise dans le déguisement, cette émotion n'est jamais poisseuse ; c'est une émotion qui désigne simplement ce qu'on aime, ce qu'on veut défendre ; c'est une émotion-valeur, une évaluation. » Roland Barthes (1983: 63)
} 


\begin{tabular}{|c|l|l|l|}
\hline $\begin{array}{c}\text { Mirror stairs } \\
\text { (See Figure }\end{array}$ & $\begin{array}{l}\text { Chanel designed her } \\
\text { "boutique" as a symbol of } \\
\text { her belonging to the } \\
\text { 5odernist avant-garde. The } \\
\text { stairs can remind us of "Nu } \\
\text { descendant un escalier" and } \\
\text { the research on moving } \\
\text { pictures by Cubism. All three } \\
\text { movies document the rue } \\
\text { Chambon original store. }\end{array}$ & $\begin{array}{l}\text { Chanel sits at the top of the "stairs to } \\
\text { heaven" as some sort of Pythic figure, } \\
\text { master of the time and of the bodies. }\end{array}$ & $\begin{array}{l}\text { Up and down the } \\
\text { social scale }\end{array}$ \\
\hline $\begin{array}{l}\text { C (name and } \\
\text { logo of the } \\
\text { brand) } \\
\text { (See Figure }\end{array}$ & $\begin{array}{l}\text { Imposing a brand means } \\
\text { finding symbols and Chanel } \\
\text { herself borrowed images } \\
\text { from her childhood in the } \\
\text { convent) to do so. }\end{array}$ & $\begin{array}{l}\text { The immediate recognition of the brand } \\
\text { brings about emotional memories in in } \\
\text { viewers familiar with the products. }\end{array}$ & $\begin{array}{l}\text { Identification of the } \\
\text { venture, the house, } \\
\text { the woman founder } \\
\text { and each product } \\
\text { emanating from that } \\
\text { ensemble. }\end{array}$ \\
\hline 6) & & & \\
\hline
\end{tabular}

\section{INSERT FIGURE 4 ABOUT HERE \\ INSERT FIGURE 5 ABOUT HERE \\ INSERT FIGURE 6 ABOUT HERE}

The last visual element mentioned in the chart above, the brand involves a well-known phenomenon in marketing: product placement. Each movie is clearly an opportunity to display the famous perfume Chanel $n^{\circ} 5$. However, it seldom happens that three movies are so entirely immerged in one brand and its universe. Consequently, the movie, as a showcase and an entertaining moment, very much resembles one of Chanel's productions. A more limited edition of this are the museum shows regularly displayed all around the world, one of them was a homage to Misia Sert (Chanel's best friend and famous muse of that time) in the Musée d'Orsay (Paris) in 2012.

A complex combination of diegesis and mimesis, Chanel's name itself has become a symbol that sentimentalism (story) and aesthetization (image) build into a unique emblem for women. As a symbol of the brand, it a recurrent figure all along the three biopics, as if to convey the idea of some sort of predestination to explain the fate of that woman. Gabrielle Bonheur Chanel was transformed into Coco Chanel (possibly her nickname when she sang in a cabaret), Coco and, as a brand, $\mathrm{C}$, present on all items manufactured and sold by the firm. This symbol is ever-present in all three movies, as a common thread. Here is one example of how the transformation operates: the movie Coco before Chanel rightfully insist that "Coco" initially signaled her low status: this was the nickname of a "grisette" (little seamstress). The character's ability to embellish this name and find her place in society is presented as related 
to her charisma, transcending class. Such is the magic power of this story that it may possibly do the same for adepts of the brand. Coco certainly thought so, to the point that it seems she herself built her own legend to make her point. However, just as she made up her life, she also proved very lucid in explaining the success of her enterprise and the rules of business in society. References to class and power are explicit in her choices and in her comments. She also mentioned how fashion works and what kind of work is involved in producing and selling it. As we can see, the grid in the movies does not allow for such additions: it combines the linearity of a life-story with the recurrence of symbols as presented in the following chart.

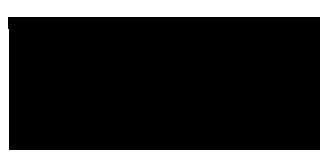

Black and white

Br

\begin{tabular}{l|l} 
Pearls & Sisters' rosary
\end{tabular}

Cigarettes (forbidden)

C brand and emblem

\section{Childhood}

Sisters' dresses at the convent and her outfit as an orphan

Sisters' rosary

Father's habits
(transgressing social and
family codes)
$\begin{aligned} & \text { Religious symbols at the } \\ & \text { Aubazine convent }\end{aligned}$

\section{Youth and love}

Coco borrows men's
clothes (ie tuxedo)

Coco is offered presents by her lovers

Coco transgresses social codes

Coco finds her style and impresses others with it
Business woman

After Boy Capel dies, Chanel supposedly invents « the little black dress »

Chanel crafts lines of jewels

Chanel creates a « drug »: Chanel n5

Chanel owns a prosperous business rue Cambon

By referring to secondary sources in a different way than the movies, I hope to "unfreeze" the story of the entrepreneurial venture and dissociate it from the brand. I introduce more dimensions to the Chanel business venture before I try to give the reasons why these dimensions are missing and more generally, why it is not easy to communicate on the most important aspects of the entrepreneurial work by relying on aesthetics.

\section{Findings: The Moving Picture of a Woman Entrepreneur and the Tale of Details}

The frame built by the three movies is somehow consistent: the entrepreneurial success of Coco Chanel has a price: it is Chanel's difference and her being denied a "normal" family life, first as a child then as an adult woman. The success of her venture is explicitly related to her ascetic dedication to work and her need to overcome her losses. She creates a consistent frame, based on clear symbols. In that regard, aesthetics and visual representations such as 
biopics contribute to the understanding of entrepreneurship. However, in the three movies, a sentimental account of personal success downplays the broader picture, and in particular, the role of a collective body of organized people at work.

One may easily understand why all three movies misrepresent Coco Chanel's life; in the same way as fashion magazines (as part of the firm's communication) and some of her biographies select a rather flattened figure of Chanel who is identified with the brand. The story must be entertaining and the character avant-garde (meaning controversial in a controlled way) so that it fits with a specific image and identity².

I consider that this stylization in the three movies creates a common grid mixing sentimentalism and aestheticism. For the purpose of making the story entertaining yet it seems to be limiting the audience's ability to understand Chanel as an entrepreneurial venture. The idealization of the founder's talent and personality ends up downplaying sociomaterial and practical dimensions, which are essential to understand entrepreneurial ventures. In the following lines, I provide additional information on some of these dimensions, because I believe they are essential to understand the role of Coco Chanel as an entrepreneur. Now my purpose is to show at least some of the messiness of this business and the constantly renewed co-production of fashion. To do this, I keep contrasting the ideal (as presented in the movies) and the material data. Instead of insisting on Chanel's class (style) I dwell on the role of social class in shaping fashion (1). In complement to her now much exposed love life, I focus on Chanel's specific role at work and her obsession with work (2). Moreover, I see Chanel's role as related to her opportunistic behavior, an important dimension of entrepreneurship (3). Finally, I point at the survival of the Chanel house and the role of Chanel herself, becoming a figure of her own making at the service of her business (owned by others) (4). These sociomaterial dimensions would probably create another type of story with different aesthetics.

1. Coco's Natural Class AND Social Class

\footnotetext{
2 Another reason is that key biographers were mostly socialites. So they contextualize and provide much more detailed accounts of Chanel's life and her way of managing her business. The parts they prove less interested with are the work dimensions, which are also absent from the movies. It should not surprise us that, as movies traditionally do, the three biopics present a stylized view of Coco Chanel's life focusing on key events. What is more surprising, however, is that they would all focus on episodes when Chanel would be a victim.
} 
Fashion aims at distinction. When creating the Chanel brand, in the movies Coco is described as someone who would "naturally" have class (as a habitus) (Bourdieu, 1984), thanks to her skill of properly identifying and using signs (Barthes, 1972). Consequently, she would help other women in this important task of being in alignment with high society. However, movies tend to essentialize this skill whereas biographers and historians tell us a different story. Coco was In fact at work for the happy few in a period when the codes were being revolutionized. The leisure class and the working class were changing in nature, causing fashion in large cities to take on more importance (Simmel, 1973). So what gave Chanel her importance was that she contributed to building a system of class that the brand is (in my view) still supporting today: the modern system of fashion depends on concepts and an implicit display of values that need to appear constantly new (the French call it "l'air du temps") as opposed to traditions (Barthes, 2006). My opinion is that this construction needs to be purposefully done by someone who keenly understands what is at stake in sporting fashion in a society where elites change and dominant coalitions fluctuate.

For instance, Chanel referred specifically to class and rank throughout her confidences to her biographers. She was herself acutely aware of their impact on social interaction and power relations. In later life, she was quoted as saying of some of her partners: "Those Grand Dukes were all the same - they looked marvelous but there was nothing behind it. Green eyes, fine hands and shoulders, peace-loving, timorous. They drank so as not to be afraid. They were tall and handsome and splendid, but behind it all - nothing; just vodka and a void" (Chanel, in Delay, 1983: 112). As a woman entrepreneur, Chanel seems to have posed as part of the "new class", a population of hardworking, self-made men and women. However, her reputation was made by spending time with the idle classes, especially the British royals. Indeed, most of her life was spent in the company of the "happy few". It seems they were her source of inspiration as much as she was theirs especially since she introduced them to all sorts of characters, among them artists.

Quite typically of an entrepreneur, Chanel was adaptable and mixed the influences of various social classes in her work. She kept making the most of opportunities created by the disruption of the social field by war and revolution. In one of the movies, that of Anne Fontaine's, Coco would be wearing a striped seaman shirt (marinière) with a very long string of pearls (sautoir) as a symbol of her ability to recreate symbols. In fact, what appears like a brilliant inspiration now should have been contextualized (war shortages, women at work and men at war) to make sense of Chanel's 
practical choices: make the most of what one has and recreate signs of distinction (Bourdieu, 1984) not with material but with arts and craft. More specifically, Coco was both a go-between in multiple "happy few" worlds and their herald abroad: it was possibly the small worlds most of her customers were attempting to copy with her guidance, and which was in turn copied by others in workshops or at home using sewing patterns and fashion magazines.

Here is one example of the importance of brokerage in Coco Chanel's entrepreneurial business. Despite her climbing the social ladder, Coco was somehow an interloper in high society, so when she made encounters, friends and enemies (sometimes both) referred it to her social origins. In Charles-Roux, the choice of eloping with the Grand Duke rather than Igor Stravinsky was interpreted by her (jealous) friend Misia Sert as a consequence of her popular origins: "Coco is $a$ little seamstress so she prefers a Grand Duke to a Genius." (Charles-Roux, 1989: 115). In fact, Chanel was the lover of both men and shared interests and projects with both whereas most of the people around her belonged to a more identified group (artists, workers, socialites, old-new money). As we shall presently see, this points at the role of strategy in governing Chanel's choices. Exposing this would tend to downplay the aura and the role of inspiration and taste and to insist more on conformism and power issues in relation to class and gender (Goffman, 1977).

In my view, she was essentially an entrepreneur and a businesswoman and this is why we remember her now. Consequently, there are other dimensions and a few facts we should have mind when reflecting upon Chanel as a social actor and the founder of a successful brand.

\section{Coco's Love AND Business Deals:}

Contrary to what the biopics tend to focus on, it seems that the center of Coco Chanel's life was work, quite a banal trait in entrepreneurs. Coco's work, however, was not essentially that of a physical worker, although she did spend a lot of time designing collections. In fact, she coordinated people who did the handy work. Both handy work and conception work are hardly glamour and entertaining: the first one is repetitive and involves a collective whereas the second is not easy to capture, since it is mostly mental.

Judging by what fashion historians and biographers tell us about her occupation, it seems that what Chanel essentially thrived in was a very particular kind of work that is characteristic of 
innovative entrepreneurship, the art of assemblage and opportunity combined in a careful balance of risk-taking. For instance, compared to many other seamstresses who launched their business at the same time, Chanel started in a fairly original way. She was not initially a seamstress with a good reputation and a strong network within the profession. Instead, she was sponsored by love money, her two lovers competing in some sort of "tournament of values." (Appadurai, 1986). They supplied her love money, a location in Paris, suppliers (Etienne Balsan's family owned very large textile factories) and shared their network of socialites who became clients for Coco.

Contrary to the script favored in the biopics, Coco was not essentially a small-scale milliner with few skills and a great deal of talent. In fact, on the basis of the very competitive hierarchy of women workers in haute couture (petites mains, premières et secondes d'atelier) based on hard work and virtuosity (Audoux, 1987), it is hardly likely Coco would have risen so far. Since Frederick Worth (in the 1860s), the field of haute couture had already been institutionalized and it was centralized in Paris where a long tradition of art and craft existed (for instance in the Faubourg Saint-Antoine). In this world, Chanel was initially an outsider with "ideas" and probably "taste". At the time, couture became an open field only at the occasion of war, when all prestigious maisons closed ${ }^{3}$

Judging by the history of fashion in the 1910s, all kinds of styles were acceptable, and customers could already access "ready-to-wear" items in catalogues or in the Bon Marché (shopping gallery in Paris pioneering large retail stores). Singer sewing machines had already conquered the world, and women would often make a lot of the family's clothes at home. So in this specific economy, Chanel went up market, targeting actresses and demi-mondaines, who

\footnotetext{
3 It seems that, unlike most milliners and "fashion houses" where women were very present and followed traditions, Chanel was original because she diversified by seizing opportunities to be different in what was perceived as an unconventional way. For instance, she used her acquaintance with Etienne Balsan to sell ready-to-wear clothes in her hat shop during the war, benefitting from the collapse of the Parisian market (deserted by its clients). This was made possible because Balsan and Capel provided love money for her first shop in the most fashionable Paris district and then in seaside resorts, Deauville, Biarritz, then Cannes, which were locations for the international elite.
} 
professionally managed their looks and competed on the social stage. They were visible in fashion magazines and could spread fashion to more conservative and more popular circles.

Looking back at this environment, it seems very unlikely that Chanel "freed" these women from their corsets and with that, created a successful brand, which is the central thesis of all three biopics and also the official story with the Chanel brand. A safer hypothesis would be to argue that Coco's success was built on a series of disruptions brought about by women as a result of the disappearance of existing "worlds" and the emergence of the modern age. Timing is essential because these changes were prompted by war.

In such a changing environment, Chanel proved a very talented strategist, a fact that is downplayed by the biopics who present her choices as mostly intuitive and emotional. One may even hypothesize that a great deal of Chanel's involvements were dictated by her professional aspirations, or if such was not initially the case, in the end, it benefited her. She was always on the lookout for new trends, sources of inspiration and rare resources such as skills and high-quality raw materials.

Throughout her career, she used her social network in high society, first the Belle-Époque provincial aristocracy and its garrison-town culture (horses, cabarets and lightentertainment), then the cosmopolitan intelligentsia in artistic Paris (with many immigrant artists like Diaghilev, Stravinsky, Picasso, Dali and many less famous around them), the royals (Russian, British, German) and the emerging stars of the movie industry in Hollywood and in Europe. These social groups were connected by key individuals (for instance Etienne de Beaumont, the Grand Duchess Alexandra Pavlova, Bendor, Misia Sert) who were both close friends and associates of Chanel's.

Here we can see both a series of disruptive changes and continuity in the world Chanel was immersed in when creating her fashion. This chain of events is an important complement to the industrial value chain to understand the specific work of an entrepreneur -both creative and adaptive- in relation to a specific environment.

\section{Coco's Talent AND her opportunism}


To contrast with the sentimental version of Coco's life, I suggest telling in a different way four important episodes of Chanel's success story. Because the project is romanticized in the biopics, their version downplays historico-social circumstances and insists on intimacy and feelings. This tends to decontextualize the venture and promote the character.

\section{Episode 1: The War changes Women's Dress}

Initially Chanel saw the First World War as an opportunity for her low-key fashion; Poiret called it "luxury wretchedness." She proved unconventional in using industrial fabric for haute couture with her Jersey factory, observing that during wars, women still sought after elegance but of a low-key type, one that allowed a more active life. Maintaining that fashion after the war was a great advantage since the price of fashionable minimalist dresses did not go down whereas more material (labour, fabric, equipment, stores) was available. Chanel created her haute couture collection re-inventing the minimalist, practical style she had defined in her first ready-to-wear jersey collections. She was now in a position to hire some of the best seamstresses for whom all the houses were in competition.

She then used her financial wealth accumulated during the war to impose herself as a leader in haute couture between the two world wars. For instance, after the Russian revolution, she used a sudden supply of cheap labor for modeling and lace confection to upgrade her offer of dresses through a partnership with the Grand Duchess Anna Pavlovna who had created a lace workshop.

\section{Episode 2: The Perfume Chanel $N^{\circ} 5$ Introduces an Industrial Cycle}

After taking the risk of launching a perfume (Chanel No. 5) using a formula created by a talented chemist (Ernest Beaux) who had been scorned by perfumers because of the novelty of his conceptual, stable scent, Chanel created an industrial partnership with the Wertheimer brothers who owned the cosmetics firm Bourjois. They later created a series of products under the brand name Chanel. At the time, the factories employed thousands of workers and the perfume became Chanel's "cash cow." This move may be called a diversification because meanwhile, Coco was still working on her collections rue Chambon in a more artisanal way.

Episode 3: Hollywood ventures Initiates the International Focus of Chanel 
After the 1929 Wall Street crisis, Chanel was contacted by the Diamond Producer Association to create a great show displaying Chanel jewelry creations (prices were down). Chanel used the pool of talents and reputation she had gathered when she had been selling imitation jewelry in the 1920s. She also benefitted from the skills of jewelers working place Vendôme. During her one-year stay in the US at the invitation of Sam Goldwyn (who offered a billion dollar deal for Chanel to dress Hollywood movie stars in the US), Chanel contacted US suppliers and distributors. She was already famous in American Fashion magazines; Vogue had documented her collections and her work in ballet and theater productions with the "Ballets Russes" and contemporary artists such as Cocteau, Picasso and Dali. As a result of her interviews and travels, the "maison Chanel" based in Paris was exporting on a global scale, whereas the production was still local.

\section{Episode 4: The Post-War Collections Reinvent the Brand to sell the Perfumes}

In 1953, the Chanel revival was orchestrated to counter Dior and continue to support the perfumes and cosmetics that were at risk of falling out of fashion. In later years, she was famous for her sober classics and she openly criticized what she perceived as the decadence in woman fashion, especially trousers and mini-skirts. She worked as a symbolic figure rue Cambon, although she had sold her shares to the Wertheimer brothers. After the war however, she was much less involved in conceiving the dresses whereas her faithful team was still at work making the garments.

These four episodes show the importance of workers and business partners along the life of the house of Chanel. Furthermore, each move includes groups of actors, which were part of different worlds (crafts, arts, cosmetic industry, entertainment) intersecting with fashion. It becomes very difficult to decide who introduced an invention or an innovation.

For instance, in the movies, the end of the corset, the little black dress and trousers are presented as Coco Chanel's gift to her fellow women. Yet the history of fashion (Steele, 2005; 1999) shows us that such is not the case, and in many instances, Chanel appropriated and radicalized inventions that were not her own. In doing so, the biopics, by focusing on Chanel's character, may be accused of denying the existence of a fashion system with its conventions (Barthes, 1967; Lipowetsky, 1994). It is based on productive value chains in a social field made up of power relations and domination (Bourdieu, 1993) and the movies seem part of a 
consumption system (Du Gay, 1996) therefore the movies aestheticize the organization directed towards users and leaves no voice to the workers (Boje, 1998). Since Chanel's fame comes from an entrepreneurial venture, although socialites and artists are important in Chanel's success, locating them outside work relations (Barley and Kunda, 2001) ends up in widening the gap between reality and fiction in viewers' representation of fashion. It symbolically recreates in the past the present secluded existence of the upper classes (PinçonCharlot, $2007 \mathrm{a} / \mathrm{b}$ ) isolated from productive forces whereas Chanel was not, as we shall see.

\section{Coco's Artists AND Workers}

According to the biopics, Chanel was an entrepreneur who took a revenge on life, since she was of modest origin. This self-made woman story is presented in reference to the social ladder and the upper class, however, it should also be considered in another light: that of her relations with co-workers. Having been poor, having been a seamstress and a dancer in a cabaret then the girlfriend of dandies might have proven inspirational (as illustrated in the movies) yet we know little of how it shaped her entrepreneurial skills in managing an organization.

Referring to everyday practices as creative resistance in de Certeau (1984), Hjorth (2004a) offers a different aesthetic perspective for entrepreneurship. They refer to everyday practices as creative resistance; instead of glorifying individual talent and personal achievement, they explore collective, popular sources of entrepreneurial ventures as a form of resistance against the existing power relations in society. In some ways, the early life of Coco Chanel corresponds is to such an upsurge. However, very soon, the success of the Chanel house is based itself on traditional work systems. Chanel had a reputation for being a tough and demanding boss, depicted as " "old style” » by her biographers (Charles-Roux, 1989; Delay, 1982; Morand,1974) in her style of management.

Information about work labor relations in the times period depicted in the movies (19101936) shows the life of workers (Castel, 1991) and the control of entrepreneurs exercised over them, as well as the domination predominance of feminine labor (Duby and Perrot, 1990; Omnès, 1997). As it happens, women were often employees in the textile industry. In couture workshops, a very conservative hierarchy of women had been observed for years and other 
women entrepreneurs like Jeanne Lanvin (Barillé, 1997; Picon, 2002) had proven were more active in implementing social reforms. Chanel was a woman who made her feminine workforce work hard and she was reputedly hard on the quality of finish of each garment. For instance, Chanel viewed the 1936 strikes and the Popular Front as a scandal as she observed it from the windows of her apartment in the Ritz. Attempting to use the war laws to avoid paying wages due, she closed her workshops (possibly retaliating against the strikes and the break of machines, possibly because of her experience of 1914-1918 when Parisian houses had gone bankrupt), firing the 300 seamstresses of the Paris workshop.

Taken in more details, Chanel's entrepreneurial moves in managing her business can be read as a very convincing illustration of entrepreneurs' as opportunity seekers skilled at brokering networks. Throughout her life, Chanel appropriated knowledge and skills from very different traditions, which she rejuvenated and celebrated with a keen sense of timing.

First, she learnt about fashion in the French Provincial Military Aristocracy when it was a very important element of sociability. Fashion was a power issue, defining a parallel hierarchy of women similar to that of the army. There were strict codes for many activities. Alluding to Chanel's influences, Charles-Roux mentions the influence of the Catholic Church and the English style for horses and sports; their relation to actresses and « grisettes » (milliners who were the mistresses of young men) as a parallel world to family obligations (described in Stendhal, Puccini, Feydeau and Proust) with alternative aesthetics and values. Chanel reinterpreted the codes when this small world collapsed as a result of World War One. At the occasion, she made a fortune and she was also freed from her inferior position in that culture. All her life, she contributed to glorify its vestiges. One of their remains was her friend and collaborator Etienne de Beaumont's nostalgic bal masqué.

Chanel used this "retro" inspiration as she used the popularity of Russian culture (Music, Dance, Lace and Perfume) after the Russian revolution. She hired immigrants as her modes and as her workforce, especially for laces and embroideries, after she had admired their lifestyle working with the Russian Ballet.

This is how she accessed artists' world, Modernism and Cubism. Working with them on shows and being patrons for the arts were competitive advantages as she rivaled with fellow fashion 
designers for artists: Schiaparelli stole Dali from her, just as Chanel had stolen artists and workers from Paul Poiret. Designers competed to set the tone and to be at the center of attention.

As part of her opportunism, is Chanel's sense of timing. The women "liberated" by Chanel were not any women, they were high society women reacting to social changes that challenged the rules of the past century; trousers, the little black dress, the flapper with her bobbed hair and the use of tweed and men's clothes as an inspiration were not Chanel's invention. Rather, she popularized them when it was first acceptable, then more or less expected to adopt the trend.

Finally, Chanel used social conventions and in particular, gender relations, as a background for her activity. It denotes a very good understanding of her environment in an age where seduction became a very important activity for men and women in modern urban society. To exist socially, both sexes had to work at their external appearance.

The art of fashion consists in creating objects but also inventing events and rituals as a stage for interactions and trades in society. There are in particular key moments such as "tournaments of values" (Appadurai, 1986; Moeran, 2011) where stakes are admittedly high since reputation and worth are at stake. Consequently, the "house" and its brand are symbols, which reflect the ambivalence of gender relationships, combining objective class alliances and struggles over divergent interests and values. The history of luxury objects show how symbolic their trade can be, at the occasion of strategic interactions for instance.

This is because men and women create specific solidarities such as the "female support systems" mentioned by Goffman (1977: 305) yet in society, pairs, family clans also create other types of coalitions, based on class. In such coalitions, men frequently pose as protectors of women: " (...) through one ritualized gesture or another, males are very likely to express, albeit fitfully, that they define females as fragile and valuable, to be protected from the harsher things of life and shown both love and respect. " (Goffman, 1977 : 308) Chanel gave men and women many occasions to play their parts successfully. She made a point of exemplifying the seduction of her creations by acting as a model and seducing men, and she displayed the men she seduced 
celebrating her with gifts. One important asset was her ability to consistently do so although she aged.

\section{Coco et la Maison Chanel: Branded}

Finally, I would like to refer the three biopics to the non-entrepreneurial Chanel, a woman who, like the actresses in the movies, was playing the part of Coco for professional reasons. The difference was that professional actresses generally have a chance to alternate roles and do not have to compete with older versions of themselves for years. So strict is the part imposed by the identity of the brand that it becomes somehow rigid. It is so pervasive that it seems to have created a grid for episodes and images, which is surprisingly similar in each biopic, despite different teams for the production.

The theme of the golden cage was used in one of Chanel's most popular communication campaign as visible in the following picture.

\section{INSERT FIGURE 7 ABOUT HERE}

The ad for Chanel perfume, Coco, reads as an ironic reflection on the use of fashion by women: it is both a pleasure and a constraint, a source of power and dependence. This ambivalence of the character (a young lady bird in a cage) contrasts with the dominant view of Chanel as embodying the "free self-assured, mature woman" who was professionally successful and reached a position of power by freeing other women. There seems to be a paradox in Chanel's black and white fashion house today, keeping women aligned with a fashion conceived some 100 years ago. Besides, both semiotics (Barthes, 2006) and symbolic interactionism (Goffman, 1977) perceive fashion as a reflect of social conventions in relation to traditions. This demands a constant attention and very few designers and models have remained in business for long. Such is the case of Chanel. This is why it is interesting to observe the transformation of an entrepreneurial venture such as Chanel's and the changing role of the foundation figure.

Chanel's later life, after 1954, when she is past 70, is spent promoting a brand which was no longer her own. Coco Chanel became the ambassador of the "maison Chanel." and remained inhabitant rue Chambon. She had already sold her shares, but chose to spend the rest of her life in the milieu and she was used for public relations. Although this is often presented as a 
unique success and the sign of a rare passion, it may also be the challenging case of a person glorifying a cult based on the image of her past. In praying at that altar, she further legitimizes and strengthens the brand. As a young character sporting new clothes, her fictional embodiments in the biopics (artificially) recreate the aura that manufactured products lack (Benjamin, 1936).

Yet, the fashion industry might only be harboring this worship of the past, and both movies and the brand cage Chanel in her house and brand as a Sybilla 4 . Here, the cage is not made of gold as in the 1990 ad campaign. It gives one the impression that Chanel was never in a position to be independent from her work, and that at one point; she became trapped in her role as a gifted professional. A lot of descriptions insist on her fastidiousness, and her fear of being obliged to change her habits or settled for a less than perfect choice in every detail of her life. The fame attached to some of her spiritual words, her habits and her personal objects seem to have exposed her intimacy to the bone. As she aged, this insistent gaze left the empress somehow naked since she had to "overplay" her persona in the media to support the prestige of her "maison". This house was her home and she was expected to be there to look for others. This is quite a paradox for the symbol of feminine emancipation.

It has already been pointed out that the ideal of the "house" can be a fake ideal of harmony, a role imposed on women in addition to their professional life (Héritier, 2007). By associating women with "home" (in a "house") like the goddess Hestia, it created for them a role as ideal wardens (Burton, 1993) safe-keepers and also prisoners (Vacchiani and Pullen, 2011). This was genuine part of "mythology" in the 1950s France (Barthes, 1957), it was still true in the 1960s US media (Goffman, 1977) and, if the three biopics are to be believed, the situation has not much changed. Coco still stayed at home, although she personally spent most of her life living in hotel rooms and using her apartment above the rue Cambon boutique only for business transactions.

\footnotetext{
4 "Nam Sibyllam quidem Cumis ego ipse oculis meis vidi in ampulla pendere, et cum illi pueri dicerent: Sibylla ti theleis; respondebat illa: apothanein thelo."
} 
I would even venture that both the "maison" and the particular role of Chanel became more and more disembodied and symbolic as the original momentum of "modern fashion" faded away. Chanel created her first collection in the age of the invention of style, when dressing oneself became more than change a social status and a function, but a deliberate expression of one's individuality (Postrel, 2003). She ended her career in the 1970s, at the peak of semiotic analysis, and from that moment on, Chanel became the incarnation of a conceptual approach to fashion. The popularity of the following quote by Chanel: "Style remains" (universal concept) if fashion (ephemeral matter) passes" show the importance of a conceptual approach to fashion among fashion designers. Accordingly, biopics seem to follow the line defined by Karl Lagerfeld as an intellectual designer. Just as Lagerfeld has played at being the reincarnation of Chanel as a performance, the Chanel characters in the biopics are greatly influenced by Karl Lagerfeld's communication choices for Chanel today ${ }^{5}$

Because of the interlacing of fiction movies in the fashion media system, the claim that Coco Chanel liberated women by stewarding her clients might be challenged. I see her role as one not so different than those tricks Goffman describes when salespersons want to "cool the mark of". Coco Chanel's role is obviously more ambivalent than that of a good fairy helping women to be free and none of the women shown in the movies seem in a position to take a step in that direction ${ }^{6}$. The movies sometimes hint at this by insisting on her suffering and her dark side. Yet the dark side of Chanel's fashion might go beyond her specific case, and refer to the need to feel an inner void with things. Consequently, this dark side of entrepreneurship would be directly related to Chanel's edge in doing business. In fact, as a fashion entrepreneur, she orchestrated a series of strategic moves that made women dependent on her products: she made them prestigious and available in small and large scales, and she used the mimetic desire of less affluent, lower class women to rapidly commoditize each new invention so that more affluent women would have to buy new clothes all the time. Therefore, to be "ahead" of

\footnotetext{
${ }^{5}$ Another illustration of this purposeful relation to the past is the show on Chanel $n^{\circ} 5$ in the Palais de Tokyo (Paris modern art museum) picturing Chanel as an inventor celebrating women.

${ }^{6}$ However, the three movies fail to identify modern women, like Coco Chanel, as performers (Butler, 1999, 1994, 1993) playing with conventions (Grove-White, 2001; Lieberman, 2000). This can be explained by the role of movies as part of the "tournament of values" in the world of fashion (Morean and Strandgaard Pedersen, 2011) where large brands compete. Their reception is part of a very pervasive media discourse (Moeran, 2006), movies being but one variation of that everyday communication about women's images.
} 
fashion, richer affluent women had in fact to "follow" Chanel's fashion. For this, the increasing role of the mass media was a key influence, portraying Chanel herself as a model, the Red Queen of her own fashion. She continued playing that role as she aged, even when she had sold her shares to her business partner.

When one closely studies images of Chanel dressed by Chanel and always at work in her famous stairs adored with its series of looking-glasses, one may interpret Chanel as an assemblage of "clichés" from the twentieth century that do not quite make a person, at least, not a hero character in a biopic. Although she popularizes the quintessential sophisticated French woman, this popular figure is but a fiction of the global age ${ }^{7}$. In archival texts and images, the Chanel house is a collective task force, a mix of classes, a mix of gender and national identities, one that has no name. Gabrielle Chanel, prisoner of Chanel fashion, remained in the service of the "Maison" she had created until the end of her life. Many of her ideas were borrowed. Most of her dresses were made by others. Her figure and her words have been appropriated by the brand's communication, and presented as a "magic spirit" just as wearing Chanel number 5 is associated with some kind of extraordinary charm.

\section{Conclusion:}

The life of Coco Chanel as it appears today in popular culture is a success story, that of a woman who found compensation for her love life in a professional success. This business was also prestigious: it meant being at the heart of fashion. The story is both edifying, associating sacrifice and genius, and mystifying, since in the end it insists on intuition and feelings. This aesthetical view is an interesting variation on entrepreneurship, yet it downplays the conscious choices made by the heroin, a skillful entrepreneur in relation to other actors in society.

In depicting Coco as a victim (she was an orphan, she lost the love of her life), the three biopics we have been studying emphasize the resilience of the heroin, making it easy to identify with her character. However, a more accurate representation of her ruse would

\footnotetext{
7 In particular, the role of the «traditional » French culture in all three biopics may point at a trouble in cultural identity, since: "Verbal and ideological decentering occurs only when a national culture sheds its closure and its selfsufficiency, when it becomes conscious of itself as only one among other cultures and languages. This new awareness will then sap the roots of the mythological sense of language, based on the notion of an absolute fusion of ideological meaning with language." (Bakhtin quoted in Todorov, 1984: 66-7)
} 
possibly prove useful, especially because of the movie's influence on millions of viewers, who may want to imitate Coco Chanel and use their talent to launch a business.

In terms of narrative plot, it would be useful to offer a different account of the life of Coco Chanel, for instance in the "unanimist" style illustrated in the French literature by contemporaries of Chanel's such as Jules Romain, who attempted to describe new group lives in the city. This would be especially important to acknowledge that entrepreneurship is a collective venture. In terms of imagery and mimesis, biopics tend to epitomize key moments so they focus on "acme moments", whereas a more day-to-day description might be more accurate. For instance, Chris Steyaert (2004) calls for more focus on 'the prosaics of entrepreneurship'. Combining it with a belief that 'creativity is . . not an exceptional condition but an everyday occurrence' (Steyaert, 2004, p. 13) means we should pay more attention to the entrepreneurial community and embrace all possible sources and types of creativity.

Although it is undoubtedly entertaining, the popular "success story" downplays the messiness of entrepreneurship and the role of historical disruption on new ventures. I would insist on some specific dimensions, which are key if we are to better understand the aesthetic dimension of entrepreneurship but do not fit with the grid and frame of a prestigious brand. First, I observe that Coco Chanel was skillful at making the most of scarce resources, her simple style being easy to reproduce by millions of home seamstresses. She was always on the lookout for new, rare resources and she would fix outfits in a form of bricolage directly on women's body. The rhythm of creation, diffusion, imitation and new creation was frequently disturbed by events of the time (wars, the Russian revolution, economic crisis) and fashion was then on the brink of a moment. The importance of momentum in defining aesthetics and business should not be downplayed because the industry has now stabilized and institutionalized itself in strong brands.

Second, the system of production in luxury as we know it emerges in the 1920s. Chanel used the skill of very talented seamstresses to first produce the dresses then a system of goods via industrial partnerships for prêt-à-porter, perfume and cosmetics. Consistent with the product placement strategy used by luxury brands, the "social life of things" (Appadurai, 1986) is 
idealized in the biopics ${ }^{8}$. Yet I believe understanding the role of each worker in the production system and his or her rewards and working conditions is also important. Coco Chanel paid great attention to it, and made choices that are interesting to contrast with the present situation of the luxury industry and fast fashion based on outsourcing via a network of global workshops.

Aesthetics in entrepreneurship is associated with artistic inspiration. However, by idealizing artists, the movies downplay the collaborative nature of both art and fashion productions. By focusing on the craft of Coco Chanel (making costumes for real life and for shows), one can see how she managed to become part of artistic collectives who mixed various influences relative to arts and traditions. The convergence between Chanel's "side activities" as an art sponsor and a socialite and her core business disappear if one identifies her work with one of a sculptor or a painter. Consequently, isolating "famous figures" such as Chanel results in ignoring the transformative nature of art groups and work on representations and values. This ignorance mirrors the movie industry and creative industries in general where firms/studios select star directors and actors and sell the copyright via diversified channels. However, more and more, active viewers may want to see behind the screen, especially since they plan to be more than just customers of ready-made images.

An active and critical audience will be interested to see how Chanel is to be remembered in the public eye: by her life rather than by her works. Her character becomes an emblem of "the modern woman" and "the fashionista" as part of a large impression management program by a group investing on its cash-cow brand: this involves prestige standards such as conveyed by love and art as opposed to volumes of sale and hard work. But it is even more interesting to see why, of all people; Coco Chanel should be the artist of the twentieth century everyone remembers. Not only is Coco made the equal of a figure like Igor Stravinsky. The large public success of the Chanel biopics contrasts with the relative oblivion of most of the contemporary artists Chanel met and worked with. By a curious twist of fate, the entrepreneur Chanel is considered as an artist whereas less entrepreneurial figures are forgotten in an age when famous artists must manage their career as a brand name.

8 This is also partly the case in Loic Prigent's 2005 documentary on the maison Chanel under Karl Lagerfeld. 


\section{References}

Appadurai, A. (1986). Introduction. In The Social Life of Things, ed. A. Appadurai. Cambridge:

Cambridge University Press, 1-72.

Audoux, M. (1987), L'Atelier de Marie-Claire (1920), Grasset, Les Cahiers Rouges, Paris

Auerbach, E. (2003), Mimesis: The Representation of Reality in Western Literature. Fiftieth

Anniversary Edition. Trans. Willard Trask. Princeton: Princeton University Press

Bakhtin, M. (1968) Rabelais and his World. Cambridge, MA: MIT Press

Bakhtin, M. (1981) The Dialogic Imagination. Austin, TX: University of Texas Press

Bakhtin, M. (1984) Problems of Dostoevsky's Poetics. Minneapolis: University of Minnesota Press.

Bakhtin, M. (1984), Rabelais and His World, Bloomington, IN: Indiana University Press.

Barillé, É. (1997), Lanvin. Thames and Hudson, Inc., London.

Barley S.R. and Kunda G., (2001), Bringing Work Back In, Organization Science, Vol. 12, No. 1, pp. 76-95

Barthes, R. (1972) Mythologies. London: J. Cape.

Barthes, R. (1981), Camera Lucida: Reflections on Photography, Hill and Wang, New York.

Barthes, R. (1982), L'Obvie et l'Obtus: Essais critiques III, Éditions du Seuil, Paris

Barthes, R. (2006), The Language of Fashion (1967), Power Publications, Sydney

Battagliola F. (2004), Histoire du travail des femmes, La Découverte, Paris.

Bazin A. (1976), Qu'est-ce que le cinéma? Editions du Cerf, Paris

Bazin, A. and S. Daney, T. Jousse, J. Narboni, J. Rivette, É. Rohmer and L. Skorecki, (2001), Critique et cinéphilie, Paris, Petite anthologie des Cahiers du cinéma, Paris

Benjamin, W. ((2008) 1936), The Work of Art in the Age of Its Technological Reproducibility, and Other Writings on Media, Harvard University Press, Harvard

Boje, D. (1998), 'Nike, Greek goddess of victory or cruelty? Women's stories of Asian factory life', Journal of Organizational Change Management, 11(6), 461-80.

Boucher F. (1965), Histoire du costume, Editions Flammarion, Paris

Bourdieu, P. (1984) Distinction: A Social Critique of the Judgement of Taste. London:Routledge.

Bourdieu, P. (1993) The Field of Cultural Production. Cambridge: Polity Press. Bourdieu, P. (1998) Acts of Resistance. Cambridge: Polity Press.

Burton, A. (2003), Dwelling in the archive: women writing house, home, and history in late colonial India. Oxford: Oxford University Press.

Butler, J. (1993) Bodies That Matter: On the Discursive Limits of Sex. New York: Routledge.

Butler, J. (1994) 'Gender As Performance: An Interview with Judith Butler' by P. Osborne and L. 
Segal, Radical Philosophy, 67 (Summer): 32-9.

Butler, J. (1999) 'Performativity's Social Magic', in R Shusterman (ed.), Bourdieu: A Critical Reader. Oxford: Blackwell. pp. 113-28.

Butler, J. (2000a) 'Agencies of Style for a Liminal Subject', in P. Gilroy, L. Grossberg and A. McRobbie (eds), Without Guarantees: In Honour of Stuart Hall. London: Verso. pp. 30-8.

Castel, R. (1991), 'From dangerousness to risk', in G. Burchell, C. Gordan and P. Miller (eds), The Foucault Effect. Studies in Governmentality, Chicago, IL: University of Chicago Press, pp. 281-98.

Cavell, S. (1979), The World Viewed: Reflections on the Ontology of Film, enlarged edition, Cambridge, MA: Harvard University Press.

Cavell, S., (1981), Pursuits of Happiness: The Hollywood Comedy of Remarriage, Cambridge: Harvard University Press.

Cavell, S., (1996) Contesting Tears: The Hollywood Melodrama of the Unknown Woman, Chicago: University of Chicago Press.

Charles-Roux E. (1989), Chanel, Collins Harvill, London.

Charles-Roux, E. (1981), Chanel and Her World, Vendome Press, New York:.

Czarniawska-Joerges B. and Rhodes C., (2003), Strong plots: Popular culture in management practice and theory in Gagliardi P. and Czarniawska, B., Management Education and Humanities, pp 95-119, Edward Elgar Publishing, Cheltenham

Czarniawska-Joerges, B. and P. Guillet de Monthoux (1994), Good Novels, Better Management. Reading Realities in Fiction, Reading, Harwood Academic Press.

Czarniawska, B. (1997), Narrating the Organization, Chicago and London:

Czarniawska, B. (1998), A Narrative Approach in Organization Studies,

Czarniawska, B. (1999) Writing Management: Organization Theory as a Literary Genre, Oxford University Press: Oxford

Daney, S. (2012), La Maison cinéma et le monde. (Tomes 1, 2, 3) Le temps des Cahiers, 1962-1981, P.O.L., Paris

De Certeau, M. (1984), The Practice of Everyday Life, Berkeley, CA: University of California Press.

De Certeau, M. (1997), Heterologies - Discourse on the Other, Minneapolis: University of Minnesota Press.

de la Haye, A., and S. Tobin (1994), Chanel: The Couturière at Work. Overlook Press, New York Delay, C., (1983), Chanel solitaire, Editions Gallimard, Paris

Dougherty, D. and Kunda, G. (1990) 'Photograph analysis: a method to capture organizational 
belief systems', in P. Gagliardi ( ed.), Symbols and Artefacts: Views of the Corporate Landscape. New York: de Gruyter, pp.185-206.

Drakopoulou-Dodd, S. and A.R. Anderson (2001), 'Understanding the enterprise culture: paradigm, paradox and policy', International Journal of Entrepreneurship and Innovation, 2(1), 13-26.

Drucker, P. (1985), Innovation and Entrepreneurship, New York: Harper and Row.

du Gay, P. (1996), Consumption and Identity at Work, London: Sage.

Duby G. and Perrot M. (dir.), (1990-1991), Histoire des femmes en Occident, Plon, Paris

Dugay, C. (2008), Coco Chanel, Lifetime, Sony Video

Essers C. (2009), Reflections on the Narrative Approach: Dilemmas of Power, Emotions and Social Location While Constructing Life-Stories, Organization, 16: 163

Essers, C. and Benschop, Y. (2007) 'Enterprising Identities: Female Entrepreneurs of Moroccan and Turkish Origin in the Netherlands', Organization Studies 28(1): 49-69.

Fontaine A., (2009) Coco before Chanel, Canal + Video

Gartner, W. (1988), 'Who is an entrepreneur?' is the wrong question, American Journal of Small Business, 12 (4), 11-32.

Gartner, W.B. (2007), 'Entrepreneurial narrative and a science of the imagination', Journal of Business Venturing, 22(5), 613-27

Geertz, C. (1988) Works and Lives: The Anthropologist as Author. Stanford, CA: Stanford University Press.

Gherardi, S. (1995) Gender, Symbolism and Organizational Culture. London: Sage.

Goffman, E. (1977), The Arrangement between the Sexes, Theory and Society, Vol. 4, No. 3. , pp. 301-331.

Grau F. M. (2007), Histoire du costume, Presses Universitaires de France, Paris

Grove-White, A. (2001), No Rules, Only Choices? : Repositioning the Self within the Fashion System in Relation to Expertise and Meaning: A Case Study of Colour and Image Consultancy Journal of Material Culture 2001 6: 193

Guerrier, Y. (2004) 'Arachne and Minerva: Women, Power and Realization', in Y. Gabriel (ed.) Myths, Stories and Organizations: Premodern Narratives for Our Times, pp. 151-64. Oxford: Oxford University Press.

Hancock, P. (2003) 'Aestheticizing the world of organization: creating beautiful untrue things', in A. Carr and P. Hancock (eds.), Art and Aesthetics at Work, Palgrave: London, pp.174-94.

Hancock, P. (2005) 'Uncovering the semiotic in organizational aesthetics' Organization, 12(1):2950.

Hatch, M-J. and Schultz, M. (2000) 'Scaling the tower of Babel: relational differences between 
identity, image and culture in organizations', in M. Schultz, M.J. Hatch and M. Larsen (eds), The Expressive Organization: Linking Identity, Reputation and the Corporate Brand. Oxford: Oxford University Press, pp. 11-35.

Héritier, F. (2007), Masculin-Féminin, 2 vol., Éditions Odile Jacob, Paris

Hjorth, D. (2004a), 'Creating space for play/invention - concepts of space and organizational entrepreneurship', Entrepreneurship and Regional Development, 16, 413-32.

Hjorth, D. (2004b), 'Towards genealogic storytelling in entrepreneurship', in C. Steyaert and D. Hjorth (eds), New Movements in Entrepreneurship, Cheltenham, UK and Northampton, MA, USA: Edward Elgar, pp. 210-29.

Hjorth, D. (2005), 'Organizational entrepreneurship: With de Certeau on creating heterotopias (or spaces for play)', Journal of Management Inquiry, 14 (4), 386-98.

Hjorth D. and Steyaert C. (2003), New Movements in Entrepreneurship, Edward Elgar Publisher, Cheltenham

Hjorth D. and Steyaert C. (2004), Narrative and Discursive Approaches in Entrepreneurship: A Second Movements in Entrepreneurship Book, Edward Elgar Publisher, Cheltenham

Hjorth D. and Steyaert C. (2009), The Politics and Aesthetics of Entrepreneurship: A Fourth Movements in Entrepreneurship Book, Edward Elgar Publisher, Cheltenham

Imas M. J., Wilson N. and Weston A. (2012) Barefoot entrepreneurs, Organization 2012 19: 563

Iser,W. (1978) The Act of Reading: A Theory of Aesthetic Response. Baltimore, MD: Johns Hopkins University Press.

Jones, C. and A. Spicer (2005), 'The sublime object of entrepreneurship', Organization, 12(2), 22346.

Jones, C. and A. Spicer (2009), Unmasking the Entrepreneur, Edward Elgar, Cheltenham Kounen, J. (2009), Coco \& Igor, Canal + Video

Labarthe, A.S. with T. Lounas, (2011), La Saga Cinéastes, de notre temps. Une histoire du cinéma en 100 films, Capricci éditions, Paris

Lieberman, S. (2000), A Matter of Taste: How Names, Fashions and Culture Change with Time. Yale University Press, New Haven

Lipovetsky, G. (1994), The Empire of Fashion. Princeton University Press, Princeton

Lounsbury, M. and M.A. Glynn (2001), 'Cultural entrepreneurship: stories, legitimacy, and the acquisition of resources', Strategic Management Journal, 22(6/7), 545-64.

Madsen, A. (1990), Coco Chanel: A Biography. Bloomsbury, London

Mauriès, P. (1993), Jewellery by CHANEL. Thames and Hudson, Inc., London

McRobbie, A. (2004) 'Post-Feminism and Popular Culture', Feminist Media Studies 4(3): 255-64. 
McRobbie, A. (2009) The Aftermath of Feminism: Gender, Culture and Social Change. London: Sage.

Mery Barnabé C. (2010), De la manufacture royale de draps à l'usine Balsan, Catalogue de l'Exposition « Châteauroux et les cités lainières d'Europe. », Châteauroux

Moeran, B and Strandgaard Pedersen, J. (eds.). (2011). Negotiating Values in the Creative Industries: Fairs, Festivals and Competitive Events. Cambridge: Cambridge University Press.

Moeran, B. (2006). More than just a fashion magazine. Current Sociology 54, 5, 725-744.

Morand, P. (1976), L'allure de Chanel. Herman, London

Müller, F. (2008), Art et Mode au xx $x^{e}$ siècle, Éditions Assouline, Paris

Nelson, J. S., Megill, A., and McCloskey, D.N. (eds) (2000) The Rhetoric of Human Sciences.

Madison, WI: University of Wisconsin Press

Nicolini D. (2009), Zooming In and Out: Studying Practices by Switching Theoretical Lenses and

Trailing Connections, Organization Studies, 30: 1391

Omnès, C. (1997), Ouvrières parisiennes. Marché du travail et trajectoires professionnelles au XXème siècle, Editions de l'EHESS, Paris

Ortner, S. (1974), 'Is female to male as nature is to culture?', in M. Rosaldo and L. Lamphere (eds), Woman, Culture \& Society, Stanford, CA: Stanford University Press, pp. 67-87.

Phillips, N. (1995), Telling Organizational Tales: On the Role of Narrative Fiction in the Study of Organizations , Organization Studies 1995 16: 625

Picon, J. (2002), Jeanne Lanvin. Editions Flammarion, Paris

Pinçon M. and Pinçon-Charlot M. (2007a), Les ghettos du Gotha. Comment les riches défendent leurs espaces. Editions du Seuil, Paris

Pinçon M. and Pinçon-Charlot M. (2007b), Sociologie de la bourgeoisie, Editions La Découverte, Paris

Pink S., L. Kurti and Afonso, A.I. (eds) (2003), Working Images: Visual research and representation in ethnography, London: Routledge, pp. 31 - 46

Pink, S. (2006) Doing Visual Ethnography. London: Sage Publications.

Pink, S. (2006) Doing Visual Ethnography. London: Sage Publications.

Postrel, V. (2003) The Substance of Style: How the Rise of Aesthetic Value is Remaking Commerce, HarperCollins Publishers, London

Prigent, L. (2005), L'esprit Chanel, Arte Vidéo, Paris

Rose, G. (2007) Visual Methodologies: An Introduction to the Interpretation of Visual Materials.

London: Sage Publications

Rose, G. (2007) Visual Methodologies: An Introduction to the Interpretation of Visual Materials. 
London: Sage Publications.

Schumpeter, J.A. (1934), The Theory of Economic Development: An Inquiry into Profits, Capital, Credit, Interest and the Business Cycle, Cambridge, MA: Harvard University Press.

Schumpeter, J.A. (1944), Capitalism, Socialism and Democracy, New York: Harper Torchbooks.

Schumpeter, J.A. (1991), Essays on Entrepreneurs, Innovations, Business Cycles, and the Evolution of Capitalism, Transaction Publishers, New Brunswick,

Schwartz, D. (1989), Visual Ethnography: Using Photography in Qualitative Research, Qualitative Sociology, 12(2), 119-145

Silverman, D., (2006), Doing Qualitative Research, A practical handbook, Sage Editions, London Simmel, G. (1973) 'Fashion', in G. Wills and D. Midgley (eds) Fashion Marketing:an Anthology of Viewpoints and Perspectives. London: Allen and Unwin.

Sørensen, B.M. (2008), “Behold, I am making all things new”: the entrepreneur as savior in the age of creativity', Scandinavian Journal of Management, 24(2), 85-93.

Stanczak G. (ed.) (2007), Visual Research Methods: Image, Society and Representation. London: Sage Publications

Steele, V. (1999), Paris Fashion: A Cultural History.( Revised edition). Berg, Oxford Steele, V. (ed.) (2005), Encyclopedia of Clothing and Fashion, Thomson Gale, Detroit Steyaert C. and Hjorth D. (2006), Entrepreneurship as Social Change: A Third Movements in Entrepreneurship Book, Edward Elgar Publisher, Cheltenham,

Taussig, M. (1993), Mimesis and Alterity: A Particular History of the Senses, Routledge Editions, New York

Vachhani, S. J. and Pullen A., (2011), Home is where the heart is? Organizing women's work and domesticity at Christmas, Organization, 18: 807

Vaughan, H. (2011), Sleeping with the Enemy. Coco Chanel's secret war, Alfred A. Knopf, New York 


\section{Appendix}

1910: Chanel opens a milliner shop sponsored by Humbert Balsan and Boy Capel 1914

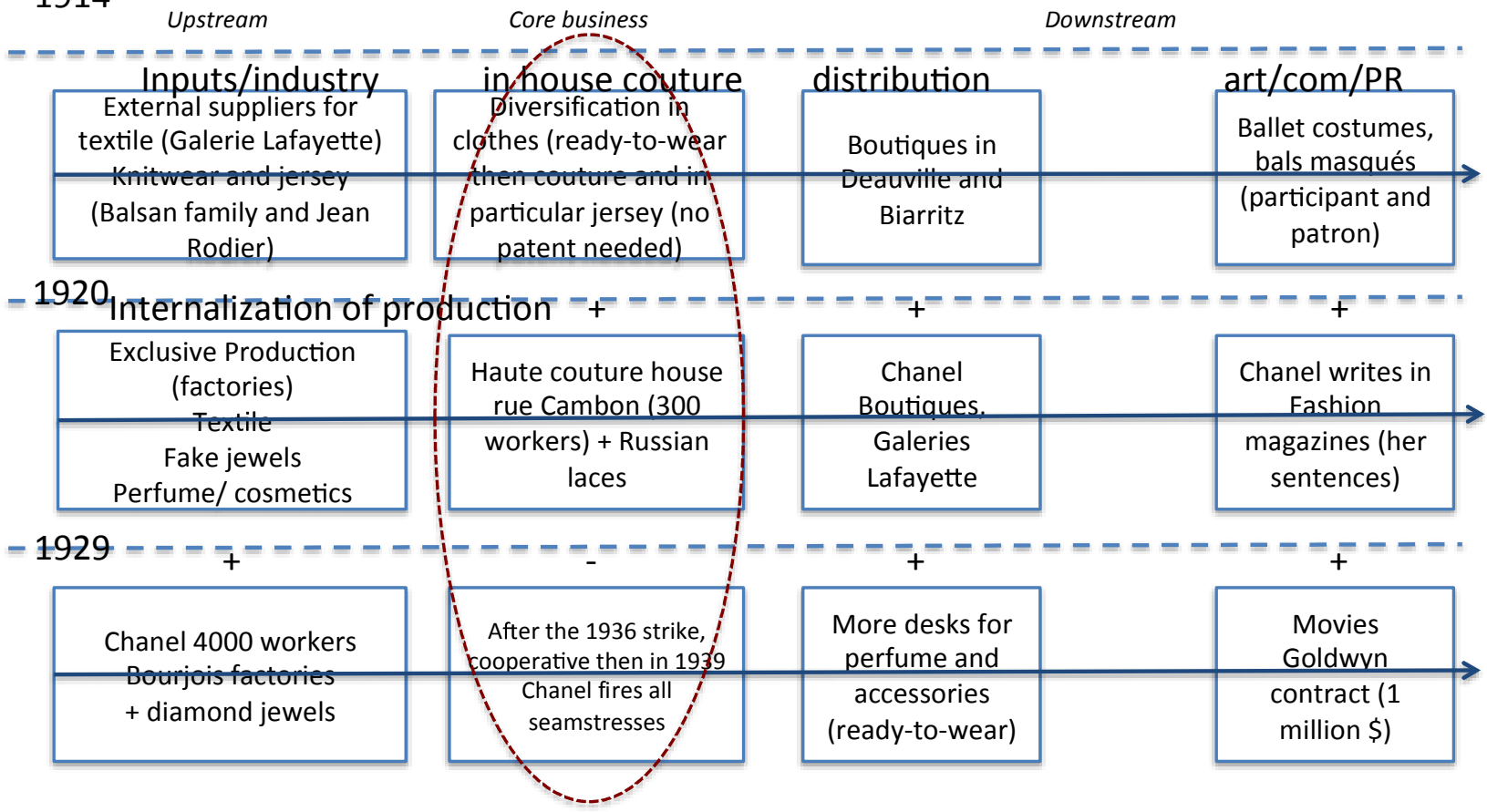

1954 Chanel sells here remaining shares of the business to the Wertheimer brothers (Bourjois)

Launch of new products (bags, shoes, new perfumes...) 